NBER WORKING PAPER SERIES

\title{
WHY ARE INDIAN CHILDREN SO SHORT?
}

\author{
Seema Jayachandran \\ Rohini Pande \\ Working Paper 21036 \\ http://www.nber.org/papers/w21036 \\ NATIONAL BUREAU OF ECONOMIC RESEARCH \\ 1050 Massachusetts Avenue \\ Cambridge, MA 02138 \\ March 2015
}

A previous version of this paper was titled, "Why Are Indian Children Shorter Than African Children?" We thank Lydia Kim, Suanna Oh, and Alexander Persaud for excellent research assistance, and Jere Behrman, Angus Deaton, Rebecca Dizon-Ross, Jean Dreze, Esther Duflo, Erica Field, Dominic Leggett, Nachiket Mor, Debraj Ray, Tomasz Strzalecki, Alessandro Tarozzi and several seminar and conference participants for helpful comments. Jayachandran acknowledges financial support from the National Science Foundation and Pande from Harvard's Women and Public Policy Program. The views expressed herein are those of the authors and do not necessarily reflect the views of the National Bureau of Economic Research.

NBER working papers are circulated for discussion and comment purposes. They have not been peerreviewed or been subject to the review by the NBER Board of Directors that accompanies official NBER publications.

(C) 2015 by Seema Jayachandran and Rohini Pande. All rights reserved. Short sections of text, not to exceed two paragraphs, may be quoted without explicit permission provided that full credit, including (C) notice, is given to the source. 
Why Are Indian Children So Short?

Seema Jayachandran and Rohini Pande

NBER Working Paper No. 21036

March 2015

JEL No. D10,O12,O53

\begin{abstract}
$\underline{\text { ABSTRACT }}$
India's child stunting rate is among the highest in the world, exceeding that of many poorer African countries. In this paper, we analyze data for over 174,000 Indian and Sub-Saharan African children to show that Indian firstborns are taller than African firstborns; the Indian height disadvantage emerges with the second child and then increases with birth order. This pattern persists when we compare height between siblings, and also holds for health inputs such as vaccinations. Three patterns in the data indicate that India's culture of eldest son preference plays a key role in explaining the steeper birth order gradient among Indian children and, consequently, the overall height deficit. First, the Indian firstborn height advantage only exists for sons. Second, an Indian son with an older sibling is taller than his African counterpart if and only if he is the eldest son. Third, the India-Africa height deficit is largest for daughters with no older brothers, which reflects that fact that their families are those most likely to exceed their desired fertility in order to have a son.
\end{abstract}

Seema Jayachandran

Department of Economics

Northwestern University

2001 Sheridan Road

Evanston, IL 60208

and NBER

seema@northwestern.edu

Rohini Pande

Kennedy School of Government

Harvard University

79 JFK Street

Cambridge, MA 02138

and NBER

rohini_pande@harvard.edu 


\section{Introduction}

One in four children under age five worldwide is so short as to be classified as stunted (UNICEF, 2014). ${ }^{1}$ Roughly half of the world's stunted children live in Asia and one third in Africa. Child stunting, a key marker of child malnutrition, casts a long shadow over an individual's life: on average, people who are shorter as children are less healthy, have worse cognitive skills, and earn less. ${ }^{2}$

In contrast to the rapid increases in height that accompanied economic growth in Western countries in recent centuries (Floud, Fogel, Harris, and Hong, 2011), economic growth and height have failed to move in tandem in Africa and Asia (Deaton, 2007). India, the world's second most populous country and the one projected to have the world's youngest population by 2020, provides a particularly stark example. Between 1992 and 2005, India's economic growth exceeded 6 percent per year, yet stunting declined by just 0.6 percentage points (1.3 percent) per year (Tarozzi, 2012). In 2005, 40 percent of Indian children under age five remained stunted (IIPS, 2010). Thus, despite a GDP per capita that is higher than roughly a hundred countries, India has the fifth highest stunting rate in the world (UNICEF, 2013). The contrast between India and Sub-Saharan African countries is particularly striking, and is the focus of this paper. India performs better on most health and economic indicators ranging from maternal mortality and life expectancy to food security, poverty incidence, and educational attainment (Ramalingaswami, Jonsson, and Rohde, 1997; Gwatkin et al., 2007). Yet, as Figure 1 shows, children born in India are, on average, shorter than those born in Sub-Saharan Africa.

In this paper, we document a set of patterns that suggests that differences in Indian parents' investments across their children contribute to India's height disadvantage. We analyze data on over 174,000 children from 25 Sub-Saharan African countries and India, drawn from recent Demographic and Health Surveys (DHS). First, we observe a much greater height drop-off for later-born children in India than in Africa: height-for-age for firstborn children

\footnotetext{
${ }^{1}$ Stunting is defined as having child height-for-age 2 standard deviations or more below the worldwide reference population median for one's gender and age in months.

${ }^{2}$ Taller people have greater cognitive skills (Glewwe and Miguel, 2007), fewer functional impairments and better immunocompetence (Barker and Osmond, 1986; Barker et al., 1993; Falkner and Tanner, 1989), and higher earnings (Strauss and Thomas, 1998; Case and Paxson, 2008). Hoddinott et al. (2013) track a cohort of Guatemalan children for over 30 years and find that those who are taller receive more schooling and demonstrate better cognitive skills, increased household per capita expenditure and a lower probability of living in poverty. An individual's adult and child height are highly correlated (Tanner et al., 1956).
} 
is actually higher in India than in Africa. The Indian height disadvantage materializes for second-born children and increases for third and higher order births, at which point Indian children have a mean height-for-age lower than that of African children by 0.3 standard deviations of the worldwide distribution. We see the same pattern - a much steeper birth order gradient in child height in India than in Africa - when the estimation only exploits between-sibling variation. Thus, birth order is not proxying for family background differences between smaller and larger families. Second, we consider an array of prenatal and postnatal health inputs; as with height, we observe a stronger drop-off with birth order in India than Africa. ${ }^{3}$

Finally, Indian children of both genders exhibit a sharper birth order gradient in height relative to African children. However, it is only among boys that we observe an Indian height advantage for firstborns. Consistent with this fact, averaged across birth orders, the Indian height deficit only holds among girls.

These patterns suggest that the prevalence of malnutrition in India is not an artifact of using child height to measure malnutrition, in which case low child height in India would simply reflect genetics. ${ }^{4}$ Genotypes do not vary with birth order or (as we discuss below) siblings' gender, so a genetic predisposition to be short would not give rise to the very significant birth order and gender composition effects that we see. Even an epigenetic explanation in which environmental factors interact with the genome, affecting gene expression, seems implausible: the fact that the same Indian children who are stunted also receive fewer prenatal and postnatal inputs makes it unlikely that the within-family stunting patterns only reflect gene expression. ${ }^{5}$

Rather, we propose that a preference for eldest sons in India - encompassing both a desire to have at least one son and for the eldest son to be healthy - generates a starkly unequal allocation of resources within families in India. This, in turn, underlies the observed birth order and gender patterns in child height. Eldest son preference can be traced to (at

\footnotetext{
${ }^{3}$ In addition, child hemoglobin levels also exhibits a steeper birth order drop-off in India.

${ }^{4}$ One approach to test for the role of genetics is to examine whether wealthy and well-fed Indian children are short by international standards. The findings are mixed (Bhandari et al., 2002; Tarozzi, 2008; Panagariya, 2013). Another approach is to examine the height of Indian children who migrate to rich countries; most authors find that the gap between the Indian-born children and worldwide norms narrows but does not close (Tarozzi, 2008; Proos, 2009).

${ }^{5}$ To cause the height patterns by birth order and gender composition that we observe in India, even in an epigenetic explanation, the environmental factor interacting with genetics would still likely need to be eldest son preference.
} 
least) two aspects of Hindu religion. First, Hinduism prescribes a patrilocal and patrilineal kinship system: aging parents live with their son, typically the eldest, and bequeath property to him (Dyson and Moore, 1983; Gupta, 1987). Second, Hindu religious texts emphasize postdeath rituals which can only be conducted by a male heir. These include lighting the funeral pyre, taking the ashes to the Ganges River, and organizing death anniversary ceremonies (Arnold et al., 1998).

Eldest son preference will generate the observed birth order gradient among boys simply because a lower birth order son is more likely to be the family's first son. Consistent with this argument, a son born at birth order 2 is taller in India than Africa if and only if he is the family's eldest son. ${ }^{6}$

Among girls, eldest son preference generates a birth order gradient through a more subtle mechanism, namely fertility stopping rules. Families who start off only having daughters are likely to exceed their desired fertility as they repeatedly try for a son. The birth of a lateparity girl is akin to a negative expenditure shock to the family, and fewer resources will be expended on her. Consistent with this, the India-Africa height gap is particularly large for daughters who only have girls as elder siblings. This pattern stands in contrast to that predicted by "sibling rivalry," where siblings compete for household resources and not having an older brother improves a child's outcomes (Garg and Morduch, 1998).

We do observe sibling rivalry in our data, even though its effect on height is outweighed by the fertility effect. First, as mentioned above, a boy born at birth order 2 fares better if he competes for resources with an older sister rather than older brother. Second, comparing prenatal and postnatal investments in girls, we find that the sibling rivalry effect dominates for in utero investments when child gender is unknown: a female fetus benefits when the parents do not yet have a male heir and hope that the pregnancy may yield the family's eldest son. However, once gender is revealed at birth and parents revise their fertility plans, postnatal investments in the same pregnancy fall off. On net, among girls, the endogenous fertility effect from not fulfilling parental demand for a son dominates, and we observe a birth order gradient in height.

\footnotetext{
${ }^{6}$ Other papers examining gender variation in height in India include Mishra, Roy, and Retherford (2004) who used the two earlier National Family Health Survey (NFHS) rounds to show that stunting in India varies with the gender composition of siblings. Tarozzi and Mahajan (2007) show that child height improved more for boys than girls between the first two NFHS waves. Also related is Coffey, Spears, and Khera (2013) who compare first cousins living in the same Indian joint household and show that children born to the younger brother in the household do worse, potentially due to their mother facing greater discrimination.
} 
Religious and regional variation in the birth order gradient within India is also consistent with the posited cultural underpinnings of India's birth order gradient. Islam places less emphasis on the importance of having a son. Comparing across Indian Hindus and Muslims, we only observe the birth order gradient in height among Hindus. Also, the height gradient is absent in Kerala, an Indian state with strong matrilineal traditions.

Explanations for the Indian birth order patterns that are unrelated to son preference are unlikely to also explain the observed patterns by child gender and siblings' gender. We also go further to rule out several alternative explanations for the Indian birth order pattern. First, other health- and environment-related factors that distinguish India from Africa such as India's higher child survival rate, worse maternal health and worse sanitation fail to account for the observed birth order patterns. Second, the reason Indian later-borns are so malnourished is not that family income declines over the lifecycle in India relative to Africa. We find that it is only among pregnant women that women's health and nutrition in India and Africa have different time profiles; Indian women do relatively worse as family size grows, but only when they are pregnant, whereas declines in family income would be evident even when women are not pregnant. Finally, other cultural factors, including greater communal care-giving in Africa and an historic preference for more family labor in Africa (related to greater land abundance) cannot explain the observed patterns.

Our findings are complementary to other research that relates environmental factors and child height, such as Spears (2013) who focuses on open defecation as a cause of the Indian height disadvantage. We emphasize the importance of a different cultural norm eldest son preference - which affects intra-household resource allocation and the take-up of services.

Cultural gender preferences and gender gaps in perceived returns to investment have been previously invoked as an explanation for unequal resource allocation across siblings, and we add to this literature (Rosenzweig and Schultz, 1982; Behrman, 1988; Garg and Morduch, 1998; Oster, 2009). We also contribute to the literature on the unintended consequences of son preference by demonstrating how dynamic fertility considerations related to the sex composition of existing children cause inequality in health outcomes between genders, among brothers, and even among sisters (Sen, 1990; Clark, 2000; Jensen, 2003; Jayachandran and Kuziemko, 2011). Relatedly, while several studies document birth order gradients in outcomes as varied as IQ, schooling, height, and personality (Behrman and Taubman, 
1986; Sulloway, 1996; Black, Devereux, and Salvanes, 2007; Savage, Derraik, Miles, et al., 2013), no prior study has examined cross-country differences in birth order effects or shown how birth order preferences, at least in some societies, are entwined with and potentially derive from gender preferences. To the best of our knowledge, this is the first paper that empirically links the literatures on birth order and quantity-quality fertility trade-offs (Becker and Lewis, 1973).

The remainder of the paper is organized as follows. Section 2 describes the data and presents descriptive statistics for the sample. Section 3 presents evidence on the birth order gradient in the Indian height disadvantage, and Section 4 presents evidence on eldest son preference as the root cause. Section 5 tests alternative explanations for the within-family patterns. Section 6 concludes.

\section{Background and Data Description}

Net nutritional intake in childhood - the nutrients consumed less those lost due to the disease environment - is reflected contemporaneously in child height and subsequently in adult height. All else equal, taller adults do better on several dimensions of individual wellbeing, a fact that points to the long-term cognitive and productivity impacts of childhood malnutrition.

The established link between child stunting and adverse long-term outcomes, as well as the relative ease of measuring child height (versus, say keeping a comprehensive food diary for a child) has led to the widespread use of height as a marker of child malnutrition. However, and especially for cross-country comparisons, it is important to account for the other key factor determining height: genetic potential. A common norm, and one we follow, is to create the child's height-for-age z-score based on the World Health Organization (WHO) growth standard for children aged 0 to 5 years. The WHO standard is designed as a universally applicable standard, describing how children should grow if they receive proper nutrition and health care. It is premised on the fact that the height distribution among children under age five who receive adequate nutrition and health care has been shown to be similar in most ethnic groups (de Onis et al., 2006; WHO, 2006). The WHO constructs the distribution of height using a sample of children from six affluent populations across five continents (children from Brazil, Ghana, India, Norway, Oman and the United States with no known health or environmental constraints to growth and who were given recommended nutrition 
and health inputs) (WHO Multicentre Growth Reference Study Group, 2006b). A z-score of 0 represents the median of the gender- and age-specific reference population, and a z-score of -1 indicates that the child is 1 standard deviation below that reference-population median. A height-for-age $\mathrm{z}$-score of -2 is the cutoff for being considered stunted.

As discussed earlier, conditional on economic performance, India remains a conspicuous negative outlier in terms of child height. The 2005-06 National Family Health Survey (NFHS3 ) is most recent Indian survey that collects child height data, is representative of India's twenty largest states, and employs the same sampling methodology and survey instrument as the internationally-used Demographic and Health Surveys. The NFHS-3 is our data source for Indian children. A widely discussed comparison for Indian children are children born in Sub-Saharan Africa, which is a region whose level of development is similar to (but on average lower than) India. It is also the comparison group used in the previous literature on the Indian height puzzle (Ramalingaswami, Jonsson, and Rohde, 1996). We therefore define as our comparison group the 25 Sub-Saharan African countries where Demographic and Health Surveys collected child anthropometric data and occurred between 2004 and 2010 (to ensure a comparable time period to NFHS-3) . Throughout this paper, the "DHS sample" refers to the set of 27 Demographic and Health Surveys for 25 Sub-Saharan African countries plus India's NFHS-3.

The DHS surveys sample and interview mothers who are 15 to 49 years old at the time of survey, and measure height for their children age five and under. ${ }^{7}$ Our sample comprises the 174,157 children for whom anthropometric data were collected in DHS surveys. In robustness checks, we also use DHS surveys from other regions. Appendix Table 1 provides summary statistics for the Indian and African subsamples, and the Data Appendix provides other survey details.

The average child age in our sample is 30.1 months in India and 28.1 months in Africa. The average height-for-age z-scores in India and Africa are -1.58 and -1.44 , respectively. A key variable of interest is child birth order, which we define based on all children ever born to a mother, currently alive or deceased. As African women have more children (3.9) than their Indian counterparts (2.7), we observe a higher fraction of high birth order children in Africa relative to India; the mean birth order is 2.6 in India and 3.7 in Africa. For the same

\footnotetext{
${ }^{7}$ Due to high incidence of missing data for children in their 60 th month of life, we limit the sample to children who are 59 months old or younger.
} 
reason of differential total fertility, the mother's average age at birth for the children in our sample is lower in India (24.8 years) than Africa (27.0 years).

We also use data on prenatal and postnatal health-related behaviors. Prenatal behavior includes the number of prenatal care visits, whether the pregnant woman received tetanus shots and iron supplementation, and delivery at a facility, and India typically outperforms Africa on these measures. (For example, 69 percent of the time, pregnant women in India took iron supplements, compared to 62 percent in Africa.). Data on health inputs for young children include whether he or she had a medical checkup within the first two months of life, whether he or she was given iron supplementation, and the total number of vaccinations. India has higher vaccination rates, while postnatal checkups and child iron supplementation are more common in Africa. Another child health outcome we examine is blood hemoglobin for child under age five, which is higher on average in India.

Appendix Table 1 also summarizes our control variables including maternal literacy, which is higher in India, and living in a rural area, which is more common in Africa. The DHS's wealth index variable measures a household's relative wealth within its country; the mean level is not comparable across countries because it is a relative measure. Additional

outcomes examined in the Appendix Tables and variables used for heterogeneity analysis are described in the Data Appendix.

\section{Birth Order and Child Outcomes}

Birth order gradients in child height have been widely examined in rich and poor countries alike (Belmont, Stein, and Susser, 1975; Behrman and Taubman, 1986; Horton, 1988; Savage, Derraik, Miles, et al., 2013). In this section we show that the relative birth order gradient in child height, as well as in health inputs that might influence height, is much larger in India than Sub-Saharan Africa.

\subsection{Child height}

Figure 2 illustrates the differences in height by birth order between India and SubSaharan Africa. The figure plots average child height-for-age (HFA) z-scores in India and Africa, separately by birth order. Among firstborn children, height in India exceeds that in Africa. An Indian deficit emerges at birth order 2 and widens for birth order 3 and higher.

Table 1 examines this pattern via regression analysis. In column (1) we show the 
average India-Africa gap, pooling all children. Indian children are, on average, 0.11 standard deviations shorter than African children.

In column (2) we disaggregate this height disadvantage by birth order. The outcome variable remains HFA for child $i$ born to mother $m$ in country $c$.

$$
\begin{aligned}
H F A_{i m c}= & \alpha_{1} I_{c}+\alpha_{2} I_{c} \times 2^{\text {nd }} \text { Child }_{i m c}+\alpha_{3} I_{c} \times 3^{r d+} \text { Child }_{i m c}+\beta_{1} 2^{\text {nd }} \text { Child }_{i m c} \\
& +\beta_{2} 3^{r d+} \text { Child }_{i m c}+\gamma X_{i m c}+\epsilon_{i m c}
\end{aligned}
$$

The variable $I_{c}$ is an indicator for Indian children. $\alpha_{1}$ is the India gap for firstborn children (omitted birth order category), and $\alpha_{2}$ and $\alpha_{3}$ capture how the gap differs for second-born children and third-and-higher birth order children. $X_{i m c}$ is a vector of controls: it always includes linear, quadratic and cubic terms for a continuous survey month-year variable (to control for differences in survey timing) and child age dummy variables (in months, to control for any sampling differences between India and Africa and to improve precision). In some specifications it also includes mother's age, child's age and household covariates interacted with the India dummy (plus main effects). Throughout, standard errors are clustered at the mother level.

As seen from the India main effect in Table 1, column (2), among firstborns, Indians are significantly taller than Africans. The India height disadvantage opens up at birth order 2 : The interaction of India and being second-born is -0.17 and highly significant. The Indian disadvantage then grows larger, with third and higher births having an HFA z-score gap of -0.32 compared to African children (sum of main effect and interaction term).

Households where a second- or third-born child is observed in the data will, on average, have a larger family size than households where a firstborn child is observed, and households with higher fertility differ along several dimensions. Thus, a key omitted variable concern is that the birth order variable in between-household comparisons could be proxying for high-fertility families (Black, Devereux, and Salvanes, 2007). A common way to address this concern is to control for family size. However, the sampling strategy in DHS surveys restricts our ability to do this directly. First, a large fraction of interviewed women have yet to complete their fertility. Second, we have height data for children age 5 and younger. Thus, we always observe height for the youngest child in the household, and birth order and family size are collinear for households where we only observe height for one child, which is 
roughly half of our sample. Therefore, we proceed by first including household covariates that strongly predict completed fertility and also control for maternal age which, conditional on current family size, is also predictive of total fertility. Next, we include mother fixed effects which allows us to fully control for family size differences by making within-family comparisons.

In column (3) we include three household covariates and their interactions with the India dummy: a household wealth index, whether the mother is literate, and whether the household is rural. These characteristics are strongly correlated with observed fertility for women aged 45 and above, who very likely have completed their fertility: literate women have one fewer child than illiterate women, fertility is higher by 0.5 children in rural areas, and a 1 standard deviation change in the wealth index is associated with 0.4 fewer children. Addition of these control variables, reduces the magnitude but not the significance of the coefficients on $I_{c} \times 2$ ndChild and $I_{c} \times 3 r d+$ Child.

Another set of concerns relates to maternal and child age. Higher birth order children are born to older mothers, so the birth order gradient might reflect an India-Africa gap in the effect of maternal age at birth on child height. In addition, birth order and child age are correlated; among siblings the higher birth order child will, by definition, be younger. We thus test the robustness to controlling for $I_{c} \times$ Mother Age and $I_{c} \times$ ChildAge, where both mother's age at birth and child's age are measured continuously (we continue to control for child age dummies). Column (4) shows that the coefficients on $I_{c} \times 2^{\text {nd }}$ Child and $I_{c} \times$ $3^{\text {rd }+}$ Child are essentially unchanged when these controls are added. ${ }^{8}$

Finally, in column (5) we include mother fixed effects and therefore only use withinfamily variation for identification. (Birth order and child's age are even more strongly correlated within a family, so we continue to control for $\left.I_{c} \times C h i l d A g e\right)$. The Indian birth order gradient remains statistically significant, and the results are similar to the unadjusted results in column (2). The fact that the India birth order gradient is larger in magnitude in column (5) than in columns (3) and (4) suggests that, conditional on the household covariates, unobserved differential selection of Indian households into higher fertility is positive. The mother fixed effect specification also demonstrates a negative birth order gradient in Africa

\footnotetext{
${ }^{8}$ We are de facto also controlling for the mother's current age, which is a linear combination of the child's age and the mother's age at birth. The results are also robust to controlling for the birth spacing between the child and his or her older sibling. Birth spacing is similar between India (mean of 36.3 months, median of 31 months) and Africa (mean of 39.0 months, median of 33 months).
} 
(the coefficients on $2^{\text {nd }}$ Child and $3^{\text {rd+ }}$ Child are negative and significant), consistent with findings in many settings that low-parity children have better outcomes. The key finding is that the birth order gradient in child height is twice as large in India as in Africa.

Height-for-age is a continuous measure of height, but one might care specifically about stunting, which is used to calculate malnutrition prevalence. Column (6) presents the mother fixed effects results using stunting (HFA z-score $\leq-2$ ) as the outcome. Relative to their African counterparts, the disadvantage for Indian second borns is 11 percentage points, and for third borns, 14 percentage points. Thus, for stunting, the high birth order penalty is two to three times as large in India as in Africa. Appendix Table 2, column (1) shows a similar pattern using height in centimeters as the outcome.

Appendix Table 2 reports additional robustness checks. To confirm that higher fertility in Africa relative to India is not driving our results, we show that the mother fixed effect specification is robust to restricting the sample to children who are birth order 4 and below (column 2) and also to dropping African surveys with fertility above the median for our full African sample (column 3). In both cases, sample restrictions imply less precisely estimated coefficients, but point estimates remain very similar to the column (5) specification in Table 1. Another potential concern is sex-selective abortion in India. In column (4), in the Indian subsample, we only keep the 25 percent of observations that are in primary sampling units where the rate of mothers reporting using ultrasound during pregnancy is below 5 percent. There are no ultrasound data in the African DHS data. Again, the standard errors increase but the point estimates remain similar. ${ }^{9}$

One final concern is that what we interpret as an abnormally steep birth order gradient in India is actually an abnormally shallow gradient in Africa. Appendix Table 3 considers alternative comparison groups. First, in columns (1)-(3) we use a comparison group defined economically rather than geographically. The comparison group comprises 18 countries from around the world that conducted one or more DHS surveys between 2004 and 2010 and whose GDP per capita in the survey year was within 50 percent (either higher or lower) of India's 2005-06 GDP per capita. Second, recent genome studies have reconstructed

\footnotetext{
${ }^{9}$ Another potential confounder is that polygamy and polygyny are more common in Africa. Polygamy would generally work against our findings, but if a woman is polygynous, then a second or third birth could be her first child with a particular partner. Appendix Table 2, column (5) shows similar results when we restrict the sample to mothers who have only had children with one partner. Finally, column (6) shows our results are robust to considering an alternative (but more endogenous) definition of birth order, namely birth order among currently living children.
} 
prehistoric migration patterns from modern-day genetic distance and show evidence of IndoEuropean migration and genetic similarity between India, Europe, Central Asia, and West Asia (Cavalli-Sforza, Menozzi, and Piazza, 1994). In columns (4)-(6) we consider the 16 European and Central and West Asian countries with DHS surveys. Given the relative paucity of surveys in this region we expand the time period to cover 1995 to 2012. In both cases, we observe a stronger birth order gradient in India than in the comparison group. The one difference is the absence of a firstborn advantage in India, which is not too surprising since, on average, these comparison groups are significantly richer than the Sub-Saharan Africa comparison group.

\subsection{Child investments}

The steeper birth order gradient in height in India relative to Sub-Saharan Africa (and other comparison groups) casts doubt on a genetic-based explanation for Indian stunting, since purely genetic differences would likely be manifested in children of all birth orders. Moreover, the persistence of this pattern even when we only make comparisons between siblings suggests that take-up of services, not access per se, underlies the Indian height deficit. In Table 2 we directly show this: the decline with birth order in prenatal and postnatal investments in children is relatively steeper in India. ${ }^{10}$

In columns (1) to (4), the outcome variables are based on retrospective information about inputs in utero and at childbirth, typically only for the youngest child in the family (rendering the sample smaller and mother fixed effect specifications infeasible). To address selection concerns, all regressions include household covariates (wealth index, female literacy, and rural residence), child's and mother's age, and their interactions with the India dummy (i.e. same specification as Table 1, column 4). On average, Indian women are more likely to obtain prenatal care, take iron supplements, and receive tetanus shots during pregnancy but are less likely to deliver at a health facility. However, for all outcomes other than tetanus shots, we observe a sharper decline with birth order in India relative to Africa. The gradient magnitudes are large enough that for two of the three inputs where the India average exceeds the Africa average (prenatal visits and iron supplementation), later-born Indian children get fewer inputs than their African counterparts. ${ }^{11}$

\footnotetext{
${ }^{10}$ The purpose of analyzing health inputs is to directly show that the resources parents allocate to their children falls sharply with birth order in India, not to make causal claims that these inputs influence height.

${ }^{11}$ As we control for household covariates interacted with India, the tables do not report the gap among
} 
Columns (5) to (7) consider three postnatal investments. The prevalence of postnatal checkup is much lower in India than Africa (reflecting an Indian social norm of maternal home confinement for forty days after birth) and child iron pill consumption is also lower. However, Indian children are more likely to get vaccinated. There in no differential birth order gradient across India and Africa for postnatal checkups and iron pill consumption. In contrast, vaccinations show a strong negative India birth order gradient. ${ }^{12}$ Column (8) shows the average effect when we pool indicator variables representing the inputs in columns (1) to (7) (see Data Appendix for further details on construction of this variable).

The birth order gradient in child health investments points to a behavioral basis for the height birth order gradient. Column (9) shows that this parental behavior affects other dimensions of child health: children's hemoglobin level exhibits a much stronger birth order gradient in India than Africa.

\section{Culture and Height Deficits}

A striking fact about the height deficit of Indian children is its concentration among later-born children. Why do Indian parents choose to have additional children but then drastically reduce investments in them? Below, we provide evidence that points to a role of Hindu norms that prioritize having at least one son.

\subsection{Gender and height deficits}

\subsubsection{Cross-country comparisons: India versus Africa}

Does the relative steepness of the birth order gradient in India vary with child gender? In Table 3, column (1) we estimate a regression of the form reported in Equation (1) but expanded to include interactions with a dummy for child gender. First, unlike with boys, the firstborn height advantage is absent for Indian girls (relative to their African counterparts). Specifically, the main effect for India implies that, on average, firstborn Indian sons are 0.15 z-score points taller than their African counterparts. However, this effect is absent for girls as the coefficient on India $\times$ Girl is -0.15 . Second, the subsequent steeper birth order gradient for Indian children is similar across genders; the triple interactions of India, higher birth

firstborns (i.e., the main effect for India). This comparison of absolute levels is based on a specification without household covariates.

${ }^{12}$ We do not examine breastfeeding as an outcome because the choice of how long to breastfeed is determined both by its health benefits and subsequent fertility (Jayachandran and Kuziemko, 2011). 
order, and the girl dummy, while negative, are statistically insignificant. In column (2) we include household covariates, child's age, and mother's age and their interactions with India. The birth order gradient patterns remain similar but the significance of the India $\times$ Girl coefficient decreases. In column (3), we include mother fixed effects and therefore compare children within the same household. While the coefficients are fairly similar, the standard errors increase considerably; we lack statistical power to examine the interaction of gender and birth order within families.

In column (4) we summarize the average gender bias in the Indian height deficit. The India dummy is small and insignificant and the coefficient on India $\times$ Girl is -0.18 . Thus, overall, only Indian girls show a child height disadvantage relative to Sub-Saharan Africa. In column (5) we include household covariates and in column (6) we estimate a regression with mother fixed effects. The coefficient of India $\times$ Girl decreases somewhat across columns but remains significant.

Columns (7) and (8) show the same specifications with the pooled prenatal and postnatal investments. Girls receive relatively fewer inputs in India, and the differential Indian birth order gradient in inputs holds for both genders. Here, we report specifications with household covariates and child and mother's age because data for most inputs was only collected for the youngest child in the family.

\subsubsection{Within-India comparisons}

In India, child height drops off strongly with birth order and, on average, the height deficit is concentrated among girls. Our hypothesis is that son preference links these two facts. As prima facie evidence, Table 4 examines whether the birth order gradient in height is accentuated for Indian religions and regions that have a stronger culture of son preference.

In column (1) we compare the birth order gradient between Indian Hindus and Muslims. Relative to Hinduism, Islam places less emphasis on needing a son for religious ceremonies, and Islamic inheritance rules disfavor women less. Several papers provide evidence that son preference, in turn, is weaker among Muslims; for example the sex ratio is less skewed among Muslims than Hindus (Borooah and Iyer, 2005) and the gender gap in child mortality is smaller (Bhalotra, Valente, and Soest, 2010). Column (1) shows that, relative to Indian Hindus, Indian Muslims have a much more muted birth order gradient.

Next, we compare Kerala and the rest of India. Historically, a distinctive feature of Ker- 
ala's social organization has been the prevalence of matrilineality, which has been linked to an absence of son preference (Oommen, 1999). Indeed, according to the 2001 census, Kerala had a male-to-female ratio among children six and younger of 1.04, which is less skewed than any other Indian state (nationwide average is 1.08) and in line with the naturally occurring ratio. Strikingly, the birth order gradient in height observed in the rest of India is absent for Kerala (column 2). Finally, we examine heterogeneity by the child sex ratio, calculated for each state-by-urban cell (which is the finest administrative level at which we can match census sex ratio data to the DHS). The sex ratio is increasing in the proportion male, so the prediction is that low-sex-ratio regions should have a smaller birth order gradient, or positive interaction terms. Here we do not find evidence of heterogeneity. ${ }^{13}$

In columns (4) to (6) we examine heterogeneity within India in prenatal and postnatal investment. Again, Muslim families exhibit less steep investment drop-offs with birth order than Hindu families, and Kerala has a less steep gradient than other Indian states. We find that states with less skewed sex ratios have a smaller relative disadvantage for birth order 2, as predicted, but not for birth order 3 and higher.

\subsection{Eldest son preference: How culture predicts height deficits}

Roughly four fifths of India's population is born Hindu. Hinduism is a religion that emphasizes the importance of male heirs - for propagating the bloodline, for inheritance, for old-age care of parents, and for cremation rituals. This has perpetuated a culture of eldest son preference among Hindu parents, who both desire at least one son and then, once the eldest son is born, prioritize him over his siblings. Below we provide evidence that suggests that this cultural norm underlies the observed birth order and gender patterns in child height.

Among boys, eldest son preference automatically generates a birth order gradient, since the eldest son is, by definition, lower birth order than his brothers. Among girls, the mechanism is more subtle and relates to fertility-stopping rules. To understand this, consider a family with fixed resources that has a desired fertility of two children but wants at least one son. ${ }^{14}$ Ex ante these two preferences are compatible because the likelihood of any child

\footnotetext{
${ }^{13}$ With eldest son preference, the sex ratio is a poor proxy for son preference because it decreases sharply with desired fertility and thus measures a mixture of son preference and desired fertility (Jayachandran, 2014).

${ }^{14}$ In our data, the majority of Indian mothers report an ideal family size of 2 children.
} 
being male is (very close to) 50 percent. If the firstborn child is a daughter, the parents will realize that they may need to exceed their desired fertility to ensure a son. They will choose how much to spend on this daughter given their available resources and an expected family size of three. Now suppose their second child is also a girl. Her birth makes it certain that they will need to exceed their desired fertility of two in order to have a son, and increases their expected family size from three to four. When her parents are choosing how much to spend on the second daughter, she will receive fewer early-life resources than her older sister did because the expected family size has increased from three to four.

For parents who do not yet have a son, each additional daughter's birth causes them to revise their fertility plans upward and reduce expenditures on the most recently born daughter in order to save for their prospective eldest son. Moreover, parents might not fully update their fertility plans when the first daughter is born but rather wait until it becomes certain that they will need to exceed their desired fertility. This myopia would amplify the extent to which the birth of second or later daughter is a positive shock to expected family size and thus to future expenses. In this manner, even absent an intrinsic parental preference for first-born daughters relative to later-born daughters, updating of fertility plans combined with fixed household resources imply fewer investments in later-born daughters. ${ }^{15}$

In this model, an elder brother, especially one born at birth order 1, is advantageous for a later-born girl. This prediction stands in contrast to the "sibling rivalry" hypothesis whereby having brothers (relative to sisters) is associated with worse outcomes for a child (Garg and Morduch, 1998). Below we will show empirically that the standard sibling competition mechanism is indeed at play, but in terms of child height, it is outweighed by the fertility stopping mechanism. In other words, the "sibling rivalry" hypothesis is germane but incomplete because it fails to account for family size being endogenous to the gender composition of siblings. One factor that distinguishes the two channels is that the fertilitystopping mechanism only materializes once child gender is known, i.e., after birth, whereas the competition mechanism exists before and after birth. ${ }^{16}$ Moreover, another prenatal advantage of no older brothers is that parents may invest heavily in the pregnancy given a 50 percent chance that the mother is pregnant with the family's eldest son. In summary, we

\footnotetext{
${ }^{15}$ Here, we describe the behavior of families that use fertility continuation rather than sex-selection to have a son; we discuss how sex selection affects our results in section 4.4.

${ }^{16}$ More precisely, before birth, the fertility-stopping mechanism is based on expected gender; the mechanism becomes stronger once gender is revealed after birth.
} 
will test the following predictions:

Prediction 1. Relative to African counterparts, later parity girls with no older brothers in India will

a. Show larger height deficits.

b. Face larger disadvantages in postnatal than prenatal investments.

Fertility-stopping behavior that is conditional on the gender of siblings also suggests that while eldest sons in India should do well regardless of birth order, those born at very late parity may suffer, as their parents significantly exceeded their desired fertility. Specifically, a family with desired fertility of two children and an eldest son born at birth order 1 or 2 need not exceed its desired fertility. By contrast, an eldest son born at birth order 3 might fare better than his sisters and better than any subsequent sons, but across families, he might be disadvantaged relative to eldest sons born at earlier birth order because his family expended resources on his two older sisters. This generates additional testable predictions related to eldest sons:

Prediction 2. Relative to African counterparts, outcomes for eldest sons in India will vary with birth order as follows:

a. Eldest sons born within their family's desired family size, even if not at birth order 1, should be favored equally.

b. High birth order eldest sons will fare worse than eldest sons born at lower birth order.

\subsection{Elder sibling composition and height deficits: Evidence}

To test the predictions laid out above we ask how, conditional on birth order, the composition of one's older siblings affects outcomes. Specifically, we estimate:

$$
\begin{aligned}
& Y_{i c m}=\alpha_{1} I_{c}+\alpha_{2} I_{c} \times 2^{\text {nd }} \text { Child }_{i m c}+\alpha_{3} I_{c} \times 3^{r d+} \text { Child }_{i m c}+\delta_{1} I_{c} \times \text { Girl }+\delta_{2} I_{c} \times \text { NoElderBro } \\
& +\delta_{3} I_{c} \times \text { Girl } \times \text { NoElderBro }+\beta_{1} 2^{\text {nd }} \text { Child } \text { imc }+\beta_{2} 3^{r d+} \text { Child }_{i m c}+\delta_{4} \text { Girl } \times \text { NoElderBro } \\
& +\delta_{5} \text { Girl }_{i m c}+\delta_{6} \text { NoElderBro } \text { imc }+\gamma X_{i m c}+\epsilon_{i m c}
\end{aligned}
$$

This is an expanded form of equation (1), where the key additional regressors are the interaction of the India dummy with a dummy for having no older brother (NoElderBro) and 
the triple interaction between India, having no older brother, and being a girl $(I \times G i r l \times$ NoElderBro). We are interested in $\delta_{2}$ which captures the differential outcome for a family's eldest son in India, and $\delta_{3}$ which captures the differential outcome for a girl in India who is either the firstborn or only has sisters as older siblings.

Table 5 reports the results. We begin by showing how the gender composition of existing children affects subsequent fertility plans differentially across India and Africa. In column (1) we use the sample of mothers and the outcome is her reported desire to have additional children. The coefficient on $I_{c} \times$ NoElderBro is negative indicating that an Indian mother who has had her eldest son is less likely to want more children. In contrast, the coefficient on $I_{c} \times$ Girl $\times$ NoElderBro is large, positive, and statistically significant. Thus, the birth of a girl in a family that only has daughters increases Indian mothers relative desire for additional children. Since the specification controls for birth order and its interaction with India, this is not simply a recast of the birth order patterns: Conditional on birth order, the gender composition of children influences mothers' preferences over fertility continuation. These findings are robust to controlling for household covariates, child's age, and mother's age interacted with India (column 2).

Next, we consider child height as the outcome variable. In column (3) we observe a positive and significant coefficient on $I_{c} \times$ NoElderBro: relative to his African counterpart, an Indian eldest son enjoys a 0.12 z-score height advantage. The coefficient on $I_{c} \times G i r l \times$ NoElderBro shows that the opposite is true for girls: having no older brother is worse than having an older brother. The net effect for girls of having an elder brother is lower in India than Africa $\left(I_{c} \times N o\right.$ ElderBro $+I_{c} \times$ Girl $\times$ NoElderBro $)$, but insignificant. The addition of controls in column (4) weakens the significance of these interaction coefficients, but the pattern of lower height for girls in India who only have sisters as elder siblings remains reasonably strong.

Further evidence on the offsetting positive and negative effects for girls of having a brother comes from comparing patterns across prenatal and postnatal investments. In general, child gender becomes known at birth (later in this section, we discuss robustness to prenatal sex determination). Prior to this (i.e., at the prenatal stage), girls without older brothers benefit from the absence of sibling rivalry and also enjoy inputs intended for the (possible) eldest son. Post-birth, the negative effects of being born a daughter in a family with no sons materialize as the parents re-optimize fertility and expenditure decisions. 
Thus, daughters without an older brother should be advantaged in terms of prenatal inputs relative to postnatal inputs. To test this prediction, we use the data on the prenatal and postnatal inputs (first examined in Table 2) and restrict the sample to girls (because the hypothesis we are testing refers to the treatment of daughters). Consistent with the negative effect of having no older brother materializing after birth (Prediction 1b), the coefficient on $I_{c} \times$ Prenatalinputs $\times$ NoElder Bro is positive and significant.

Next, we consider the predictions for eldest sons. Column (3) allows us to test Prediction 2a, which is that eldest sons born at later parity should also be favored, at least as long as they were born within their family's desired family size. The relative Indian advantage for an eldest son at birth order 2 in India is given by $I_{c}+I_{c} \times 2^{\text {nd }}$ Child $+I_{c} \times$ NoElder Bro, which is positive and significant (p-value of 0.048 reported in column 3). Meanwhile, consistent with Prediction 2b assuming families want two children (the modal preference in India), an eldest son born at birth order 3 does worse in India than Africa (p-value of 0.004).

Certainly eldest son preference does not explain all observed birth order patterns. For example, in unreported results, we observe a birth order gradient even between the family's second and third sons. Nonetheless, several patterns in the data point strongly to eldest son preference being an important determinant of resource allocation across siblings and of fertility stopping behaviors in India. As a consequence, a cultural norm of eldest son preference contributes to low child height in India and, relatedly, the strong birth order gradient for child height that we document.

\subsection{Robustness to sex-selection}

The above analysis assumes that a child's sex is exogenous, but sex-selective abortions may render observed child gender, especially among later parity children, endogenous in India. In this subsection, we discuss how sex selection could affect our results.

Sex selection could cause differential selection into high fertility in India compared to Africa (where sex-selection is much less common). The use of sex-selective abortion in India varies with the mother's literacy, for example (the use of ultrasound is more common among literate women, and the sex ratio of their children is more skewed). If literate mothers are more likely to use sex-selection to ensure a son within their desired family size of two or three, while illiterate mothers instead just continue having children to try for a son, then sex selection could cause poorer families to be relatively overrepresented at high birth order 
in India. This selection could cause bias because mother's literacy likely has direct effects on child height. However, this type of selection does not seem to be biasing our estimates of the steeper birth order gradient in India. Our results in Table 1 already sought to address the more general possibility of differential selection into high fertility in India versus Africa. The India-Africa gap in the birth order gradient is robust to allowing for differential effects by maternal literacy (and other family characteristics potentially correlated with use of sex selection) in India, as well as to using family fixed effects. In addition, the steeper birth order gradient in India is similar when we restrict the Indian subsample to primary sampling units (PSUs) with low ultrasound use (Appendix Table 2, column 4).

Thus, the type of selection problem that we have not yet addressed is related to child gender: sex-selection could cause differential selection into having high parity girls; when we observe girls at birth order 2 or 3 , for example, they might be from relatively less literate households in India. This selection problem could be exacerbated when we condition on older siblings' gender. For example, more educated Indian households could be overrepresented in the group whose first-born is a daughter and second-born is a son.

It is important, therefore, to check if sex-selection biases our results when the regressions exploit variation in child's gender and siblings' gender, e.g., those reported in Table 5. Maternal education appears to be one of the strongest predictors of sex-selection in India (Pörtner, 2014). ${ }^{17}$ It would be worrisome if our results were entirely driven by the literate subsample, where the assumption of exogenous child gender is tenuous. Appendix Table 4 examines the same specifications as Table 5, columns (3)-(4) - how does height vary with whether you have an older brother? - separately for the subsamples of illiterate women and literate women. Reassuringly, the results are similar across the two subsamples; in particular, the coefficient on $I_{c} \times$ Girl $\times$ NoElderBro is very similar across the specifications.

Use of sex-selection is more common in urban areas, so columns (5) to (8) of Appendix Table 4 compare the results in rural and urban areas. Again, the coefficients of interest are similar across the two subsamples. Finally, in columns (9) and (10) we restrict the Indian subsample to those PSUs with very low use of ultrasound, and the negative effect of having no older brother on girls' height becomes stronger. This pattern is, in fact, what we would

\footnotetext{
${ }^{17}$ Self-reported ultrasound use during pregnancy is 47 percent among literate women but only 12 percent among illiterate women in India. The sex ratio in our Indian subsample at birth order 2 is 1.13 for literate women and 1.06 among illiterate women. Ultrasound use in urban versus rural areas is 51 percent versus 20 percent. The sex ratio at birth order 2 is 1.14 in urban areas and 1.08 in rural areas.
} 
predict. The fertility-stopping mechanism that generates this counterintuitive advantage of having an older brother is only pertinent for families that use fertility continuation rather than sex-selection to obtain their eldest son.

In short, while child gender is certainly not exogenous in India, at least beyond birth order 1, the key empirical patterns that we document - both the birth order gradient in child height and the additional patterns that suggest the root cause is eldest son preference - do not seem to be an artifact of selection bias caused by use of sex-selective abortions. In fact, our argument is that eldest son preference generates a birth order gradient partly via families trying again for a son, so it is reassuring that some of our predictions are seen more strongly among "try again" families than among those that use sex-selection to obtain a son.

\section{$5 \quad$ Alternative Explanations}

We argue that cultural norms that privilege the eldest son in India can help explain the observed drop-off in resource allocation across siblings, and the resulting high rate of child stunting. Below, we examine the empirical support for three classes of alternative explanations for the height patterns: other health-related explanations, economic conditions, and other norms related to child-rearing practices.

Note that in addition to the evidence we present below, alternative explanations for the birth order gradient in height would generally not predict the several other patterns observed. These patterns include how height varies with older siblings' gender, how health inputs vary with birth order and gender, and how having an older brother differentially impacts girls' prenatal versus postnatal inputs. In this sense, eldest son preference is likely unique in offering a parsimonious explanation for not just the birth order gradient but also a suite of other facts.

\section{Health and disease environment}

Mortality selection among children. Infant mortality is lower in India than Sub-Saharan Africa. It is therefore natural to expect that relatively weak (and short) children are more likely to survive through childhood in India than Sub-Saharan Africa. This, in turn, would lower observed average child height in India relative to Africa. For mortality selection to further explain India's relatively steeper birth order gradient, infant survival in India would need to be especially high for later-born children (where the largest Indian height disadvantage is 
observed). In column (1) of Appendix Table 5 we show the opposite holds; infant mortality among children of later birth order is significantly higher in India than Africa. This fact militates against the possibility that mortality selection underlies the steeper height gradient in India. Moreover, it is consistent with later-born Indian children being relatively more malnourished and provides additional evidence that later-born Indian children fare poorly.

Maternal health. Indian mothers are on average six centimeters shorter than Sub-Saharan African mothers (1.52 meters versus 1.58), and this, arguably, reflects the fact that Indian women's health at the beginning of their childbearing years is worse. It is plausible that across successive childbirths, Indian mothers' health deteriorates more rapidly to the detriment of infant health. This possibility is related to Deaton and Drèze's (2009) gradual catch-up hypothesis which posits that it could take generations to close the height gap in India if a mother's malnutrition and poor health as a child, in turn, affect her children's size.

To test this hypothesis, we ask whether mothers' childhood malnutrition and poor health, as proxied by their height, have differential effects by birth order. Column (2) of Appendix Table 5 presents regressions where we include interactions between mother's height and birth order as additional covariates. This allows us to examine whether there is an effect of maternal height that varies by child's birth order and can "knock out" the stronger birth order gradient in India. The key coefficients on Mother'sHeight $\times$ BirthOrder dummies are positively signed but small and statistically insignificant. Importantly, they leave the coefficients on India interacted with higher birth order dummies unaffected.

Disease environment Another possibility is that later born Indian children face a worse disease environment, related to poor sanitation. The likelihood that a household reports open defecation is 46 percent in India and 32 percent in Sub-Saharan Africa. Spears (2013) points to the high rate of open defecation in India as a contributor to the prevalence of child stunting. Even if a household's sanitation infrastructure does not change over time, later-born children may have more exposure to disease because older siblings expose them to pathogens or they receive care from inferior caregivers. Appendix Table 5, column (3) examines whether there is a stronger birth order gradient for diarrhea in India. Indian mothers' responses suggest an increase in the likelihood that third and later-born children have had diarrhea in last two weeks, but the effect size is small. Column (4) directly examines whether open defecation can (statistically) explain the India birth order gradient. The point estimates suggest that 
the prevalence of open defecation has, if anything, smaller consequences for height for higher birth order children; in any case, controlling for the rate of open defecation does not diminish the magnitude of the India-Africa birth order gradient in child height. Needless to say, it remains possible that open defecation contributes to low child height in India; absent open defecation, the intercept term for India could be higher.

\section{Economic conditions}

Higher birth order children are born later in their parents' lives, on average. If families have a limited ability to intertemporally smooth consumption, then resources available per child will vary with the time profile of household income. If Indian parents have relatively less income than Sub-Saharan African parents when later parity children are born, then these children may receive relatively fewer resources and have worse outcomes. (Here, age, or more specifically marriage duration, is the relevant measure of "time," rather than calendar time. $)^{18}$

This is perhaps the most challenging alternative to test; while we can compare child height across siblings, we lack time-varying measures of household income or wealth that capture the family's resources when those siblings were born. Instead, we provide an indirect test: holding constant number of children born, we compare maternal nutritional inputs and outcomes across pregnant and not-pregnant women. If Indian households have less income over time, then maternal food consumption should decline in India relative to Africa, independent of their pregnancy status. In contrast, our preference-based explanation suggests that later-in-life declines in maternal consumption should be concentrated among pregnant women.

Data on food consumption were collected for Indian and Sub-Saharan African mothers who have given birth in the last three years (hence, our sample excludes women who have no children or are pregnant with their first child). We create a consumption index which averages five indicator variables for whether the mother reports consuming specific food items during the recall period. The data are fairly crude, asking whether the mother consumed a type of food but not the amount, but they give an indication of dietary diversity and the nutritional inputs for women. Essentially everyone has consumed starchy foods, so we focus on the categories with variation (and which are important sources of protein and vitamins),

\footnotetext{
${ }^{18} \mathrm{~A}$ related idea, which seems less plausible but is possible, is differences in the lifecycle profile of prices.
} 
namely leafy vegetables, fruit, dairy, and meat/fish/eggs. The regression specification allows impacts to vary by a woman's pregnancy status, family size, and their interaction.

Appendix Table 6, column (1) shows a sharper birth order gradient for pregnant Indian women (the omitted category), i.e., a greater drop-off in food consumption across successive pregnancies. Thus, Indian mothers who are pregnant with their third or higher birth order child are disadvantaged nutritionally. (Indian women report higher consumption levels than African women across all pregnancies; our results demonstrate that the gradient is sharper for Indians.) The point estimates also suggest a much smaller relative decline in consumption among non-pregnant Indian mothers (positive triple interaction term for India, has two or more children, and not pregnant). This evidence weighs against different time profiles of income. In column (2) we consider mother's hemoglobin levels as the outcome and again observe a differential gradient among women as they have more children. And as with food consumption, this gradient varies with a woman's pregnancy status. Specifically, across successive pregnancies the drop off for Indian mothers exceeds that for Sub-Saharan African mothers (negative coefficients for India interacted with number of children), but the gradient is much smaller among non-pregnant women (positive triple interactions). This is further evidence against the hypothesis that financial resources of Indian households dropping off more steeply over the lifecycle compared to African households underlies the observed birth order patterns.

A complementary test is to consider the sample of Indian couples where we observe consumption outcomes for both spouses. (The male consumption module is, unfortunately, fielded in very few Sub-Saharan African surveys.) A caveat is that nutritional needs vary by gender, and differentially so when a woman is pregnant. Also, the age profile of hemoglobin differs between even healthy men and women and is affected by pregnancy. The results in columns (3) and (4) are noisy but the pattern of coefficients mirrors that in columns (1) and (2). Declines in food consumption in India as family size increases are concentrated among pregnant women and do not extend to their husbands. Hence, the gender gap in consumption widens during pregnancies, suggesting differential investment in children rather than a general decline in the way women are treated over time. We do not see the same pattern for hemoglobin, however. 


\section{Other cultural norms}

Communal child-rearing In addition to income, another constrained resource is parental time. Parents might have less time to take care of later-born infants because they also have older children to look after. One reason this scarcity of time might be more acute in India is because in Sub-Saharan Africa there is a possibly stronger norm of relatives and neighbors helping raise children (Goody, 1982; Akresh, 2009). We create a proxy for the extent of "communal child-rearing" at the PSU level, namely the proportion of women's children under age 10 years who are non-resident in their household. This proportion is indeed higher in Africa (9.8 percent) than India (2.3 percent). This factor, however, does not explain the India-Africa differential birth order gradient. Appendix Table 5, column (5) shows that while the extent of communal child-rearing does indeed dampen the birth order gradient, the effect size and gap in this practice across Sub-Saharan Africa and India are too small to explain much of the stronger birth order gradient in India.

Land scarcity A final possibility we consider is that the high relative investment in earlier born children in India reflects historical land scarcity. In Africa, where land is more abundant, later born children could have been (and could still be) more valuable in helping with agriculture. We test this idea by using the 1961 ratio of population to land area as a proxy for historical land scarcity. By this metric, land is indeed more scarce in India than Africa. However, as shown in Appendix Table 5, column (6), this factor cannot explain why height drops off so steeply with birth order in India.

\section{Conclusion}

This paper sheds light on the puzzlingly high rate of stunting in India by comparing child height-for-age in India and Sub-Saharan Africa. We present three facts that support the "environment" side in the genes-versus-environment debate and, more specifically, point to parents' intra-family allocation decisions as a key factor underlying child malnutrition in India. First, among firstborns, Indians are actually taller than Africans; the height disadvantage appears with the second child and increases with birth order. The particularly strong birth order gradient in height in India is robust to including family fixed effects, which helps rule out most selection concerns. Second, investments in successive pregnancies and higher birth order children decline faster in India than Africa. Third, the India-Africa birth order 
gradient in child height is larger for boys if the family has a son already; Indian parents seem to disinvest in their subsequent children once their eldest son is born. Meanwhile, for Indian girls, second-borns are relatively disadvantaged by having no elder brothers, consistent with the family conserving resources in anticipation of having another child to try for a son. These facts suggest that parental preferences - specifically, a strong desire to have and invest in an eldest son - underlie much of India's child stunting.

One might expect unequal allocation in the household to matter less as India develops. With greater financial resources, all children might be well nourished enough to achieve their height potential. However, when we compare households by wealth, the Indian birth order gradient in height is actually relatively larger among wealthier households. Thus, India appears to still be far from the level of wealth at which, despite unequal allocation, children are all sufficiently nourished. This implies that even as India develops, the problem of malnutrition might be slow to fade, unless policies are put in place that influence or counteract the intrahousehold allocation decisions that parents are making. Moreover, eldest son preference leads parents to invest in their children unequally in ways that extend beyond malnutrition. For instance, do investments in children have diminishing returns? If so, the skewed parental decisions that we have shown could be depressing India's total human capital and economic growth - as well as creating within-family inequality. 


\section{References}

Akresh, R. (2009): "Flexibility of Household Structure: Child Fostering Decisions in Burkina Faso," Journal of Human Resources, 44(4), 976-997.

Arnold, F., Et AL. (1998): "Son Preference, the Family-Building Process and Child Mortality in India," Population Studies, 52, 301-315.

Barker, D. J. P., ET AL. (1993): "Fetal Nutrition and Cardiovascular Disease in Adult Life," The Lancet, 341(8850), 938-941.

Barker, D. J. P., And C. Osmond (1986): "Infant Mortality, Childhood Nutrition, and Ischaemic Heart Disease in England and Wales," The Lancet, 327(8489), 1077-1081.

Becker, G. S., And H. G. Lewis (1973): "On the Interaction Between the Quantity and Quality of Children," 81(2, Part 2), S279-S288.

Behrman, J. R. (1988): "Nutrition, Health, Birth Order and Seasonality: Intrahousehold Allocation among Children in Rural India," Journal of Development Economics, 28(1), $43-62$.

Behrman, J. R., And P. Taubman (1986): "Birth Order, Schooling, and Earnings," Journal of Labor Economics, 4(3).

Belmont, L., Z. A. Stein, And M. W. Susser (1975): "Comparison of Associations of Birth Order With Intelligence Test Score and Height," Nature, 255(5503), 54-56.

Bhalotra, S., C. Valente, and A. V. Soest (2010): "The Puzzle of Muslim Advantage in Child Survival in India," Journal of Health Economics, 29(2), 191-204.

Bhandari, N., ET AL. (2002): "Growth Performance of Affluent Indian Children Is Similar to That in Developed Countries," Bulletin of the World Health Organization, 80(3), 189195.

Black, S., P. Devereux, and K. Salvanes (2007): "Older and Wiser? Birth Order and IQ of Young Men," National Bureau of Economic Research Working Paper No. 13237.

Borooah, V. K., And S. Iyer (2005): "Religion, Literacy and the Female-to-Male Ratio," Economic and Political Weekly, 40(5), 419-427.

Case, A., And C. Paxson (2008): "Stature and Status: Height, Ability, and Labor Market Outcomes," Journal of Political Economy, 116(3), 499-532.

Cavalli-Sforza, L. L., P. Menozzi, and A. Piazza (1994): The History and Geography of Human Genes. Princeton University Press, Princeton, NJ.

Clark, S. (2000): "Son Preference and Sex Composition of Children: Evidence from India," Demography, 37(1), 95-108. 
Coffey, D., D. Spears, and R. Khera (2013): "Women's Status and Children's Height in India: Evidence from Joint Rural Households," Working paper.

De Onis, M., A. W. Onyango, E. Borghi, C. Garza, H. Yang, et Al. (2006): "Comparison of the World Health Organization (WHO) Child Growth Standards and the National Center for Health Statistics/WHO International Growth Reference: Implications for Child Health Programmes," Public Health Nutrition, 9(7), 942-947.

Deaton, A. (2007): "Height, Health and Development," Proceedings of the National Academy of Science, 104(33), 13232-13237.

Deaton, A., and J. Drèze (2009): "Food and Nutrition in India: Facts and Interpretations," Economic \& Political Weekly, 46(7), 42-65.

Dyson, T., And M. Moore (1983): "On Kinship Structure, Female Autonomy, and Demographic Behavior in India," Population and Development Review, 9(1), 35-60.

FAlkner, F., And J. TAnner (1989): "The Low-Birth-Weight Infant," in Human Growth: A Comprehensive Treatise, ed. by F. Falkner, and J. Tanner, vol. 1, pp. 391-413. Plenum, New York.

Floud, R., R. W. Fogel, B. Harris, And S. C. Hong (2011): The Changing Body: Health, Nutrition, and Human Development in the Western World Since 1700. Cambridge University Press.

Garg, A., And J. Morduch (1998): "Sibling Rivalry and the Gender Gap: Evidence from Child Health Outcomes in Ghana," Journal of Population Economics, 11(4), 471-493.

Glewwe, P., And E. A. Miguel (2007): "The Impact of Child Health and Nutrition on Education in Less Developed Countries," in Handbook of Development Economics, ed. by T. P. Schultz, and J. Strauss, vol. 4, pp. 3561-3606. Elsevier, Amsterdam.

Goody, E. (1982): Parenthood and Social Reproduction: Fostering and Occupational Roles in West Africa. Cambridge University Press, Cambidge, UK.

Gupta, M. D. (1987): "Selective Discrimination Against Female Children in Rural Punjab, India," Population and Development Review, 13(1), 77-100.

Gwatkin, D., et AL. (2007): "Socio-Economic Differences in Health, Nutrition and Population Within Developing Countries: An Overview," Health, Nutrition and Population Network Informal Paper Series, World Bank.

Hoddinott, J., ET AL. (2013): "Adult Consequences of Growth Failure in Early Childhood," American Journal of Clinical Nutrition.

Horton, S. (1988): "Birth Order and Child Nutritional Status: Evidence from the Philippines," Economic Development and Cultural Change, 36(2), 341-354.

IIPS (2010): District Level Household and Facility Survey (DLHS-3), 200\%-08. International Institute for Population Sciences, Mumbai. 
Jayachandran, S. (2014): "Fertility Decline and Missing Women," Working Paper 20272, National Bureau of Economic Research.

Jayachandran, S., And I. Kuziemko (2011): "Why Do Mothers Breastfeed Girls Less Than Boys: Evidence and Implications for Child Health in India," Quarterly Journal of Economics, 126(3), 1485-1538.

Jensen, R. (2003): "Equal Treatment, Unequal Outcomes? Generating Sex Inequality Through Fertility Behavior," Mimeo, Harvard University.

Mishra, V., T. K. Roy, and R. D. Retherford (2004): "Sex Differentials in Childhood Feeding, Health Care and Nutritional Status," Population and Development Review, 30(2), 269-295.

Oommen, M. A. (1999): Rethinking Development: Kerala's Development Experience, vol. 2. Concept Publishing Company, New Delhi.

Oster, E. (2009): "Does Increased Access Increase Equality? Gender and Child Health Investments in India," Journal of Development Economics, 89(1), 62-76.

PanagariyA, A. (2013): "Does India Really Suffer from Worse Child Malnutrition Than Sub-Saharan Africa?," Economic and Political Weekly, 48(18).

Pörtner, C. C. (2014): "Sex Selective Abortions, Fertility, and Birth Spacing," mimeo, Seattle University.

Proos, L. A. (2009): "Growth and Development of Indian Children Adopted in Sweden," Indian Journal of Medical Research, 130, 646-650.

Ramalingaswami, V., U. Jonsson, and J. Rohde (1996): "Commentary: The Asian Enigma," The Progress of Nations, UNICEF, (available at www.unicef.org/pon96/ nuenigma.htm).

(1997): "Malnutrition: A South Asian Enigma," in Malnutrition in South Asia: A Regional Profile, ed. by S. Gillespie, no. 5, pp. 11-22. UNICEF Regional Office for South Asia, Kathmandu, Nepal.

Rosenzweig, M. R., And T. P. Schultz (1982): "Market Opportunities, Genetic Endowments, and Intrafamily Resource Distribution: Child Survival in Rural India," The American Economic Review, 72(4), 803-815.

Savage, T., J. G. B. Derraik, H. L. Miles, et Al. (2013): "Birth Order Progressively Affects Childhood Height," Clinical Endocrinology, 79(3), 379?-385.

Sen, A. (1990): "More Than 100 Million Women Are Missing," New York Review of Books, $37(20)$.

Spears, D. (2013): "How Much International Variation in Child Height Can Sanitation Explain?," Mimeo, Princeton University. 
Strauss, J., and D. Thomas (1998): "Health, Nutrition, and Economic Development," Journal of Economic Literature, 36(2), 766-817.

Sulloway, F. J. (1996): Born To Rebel. Pantheon, New York.

Tanner, J., M. Healy, R. Lockhart, J. MacKenzie, and R. Whitehouse (1956): "Aberdeen Growth Study: I. The Prediction of Adult Body Measurements from Measurements Taken Each Year from Birth to 5 Years," Archives of Disease in Childhood, 31(159), 372.

TArozzi, A. (2008): "Growth Reference Charts and the Nutritional Status of Indian Children," Economics and Human Biology, 6(3), 455-468.

(2012): "Some Facts about Boy versus Girl Health Indicators in India: 19922005," CESifo Economic Studies, 58(2), 296-321.

Tarozzi, A., And A. Mahajan (2007): "Child Nutrition in India in the Nineties," Economic Development and Cultural Change, 55(3), 441-486.

UNICEF (2013): Improving Child Nutrition: The Achievable Imperative for Global Progress. UNICEF, New York.

(2014): "Levels and Trends in Child Malnutrition: UNICEF/WHO/The World Bank Joint Child Malnutrition Estimates," Discussion paper.

WhO Multicentre Growth Reference Study Group (2006a): "Assessment of Differences in Linear Growth Among Populations in the WHO Multicentre Growth Reference Study," Acta Paediatrica, 450.

(2006b): WHO Child Growth Standards: Methods and Development. World Health Organization, Geneva, (available at http://www.who.int/childgrowth/standards/ technical_report/en/index.html). 
Figure 1: Child height versus national GDP

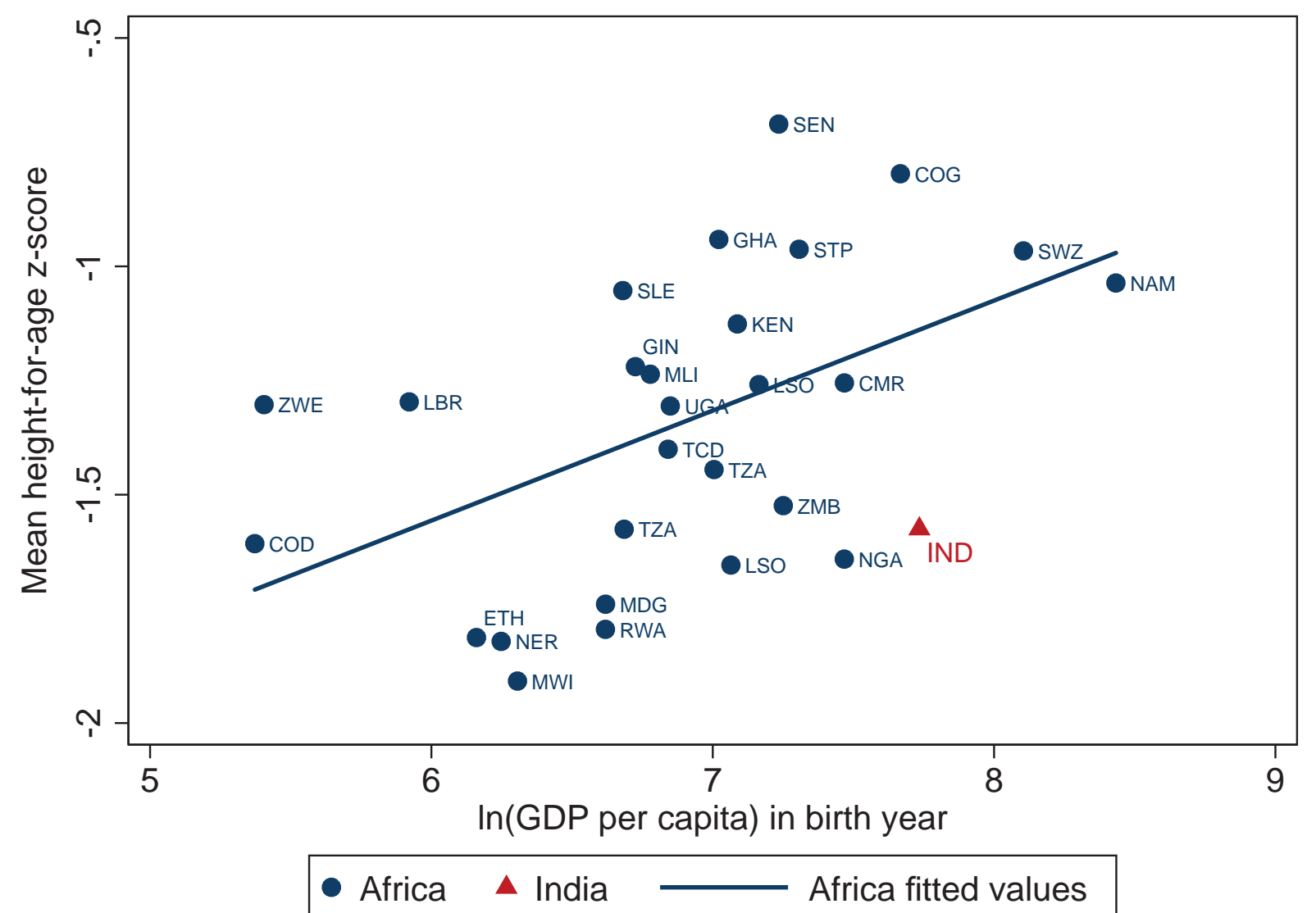

The blue dots and red triangle indicate survey-specific means for Sub-Saharan Africa and Indian surveys, respectively. The mean is calculated over all children less than 60 months old with anthropometric data. The blue line is the best linear fit for Sub-Saharan Africa. 
Figure 2: Child height in India and Africa, by child's birth order

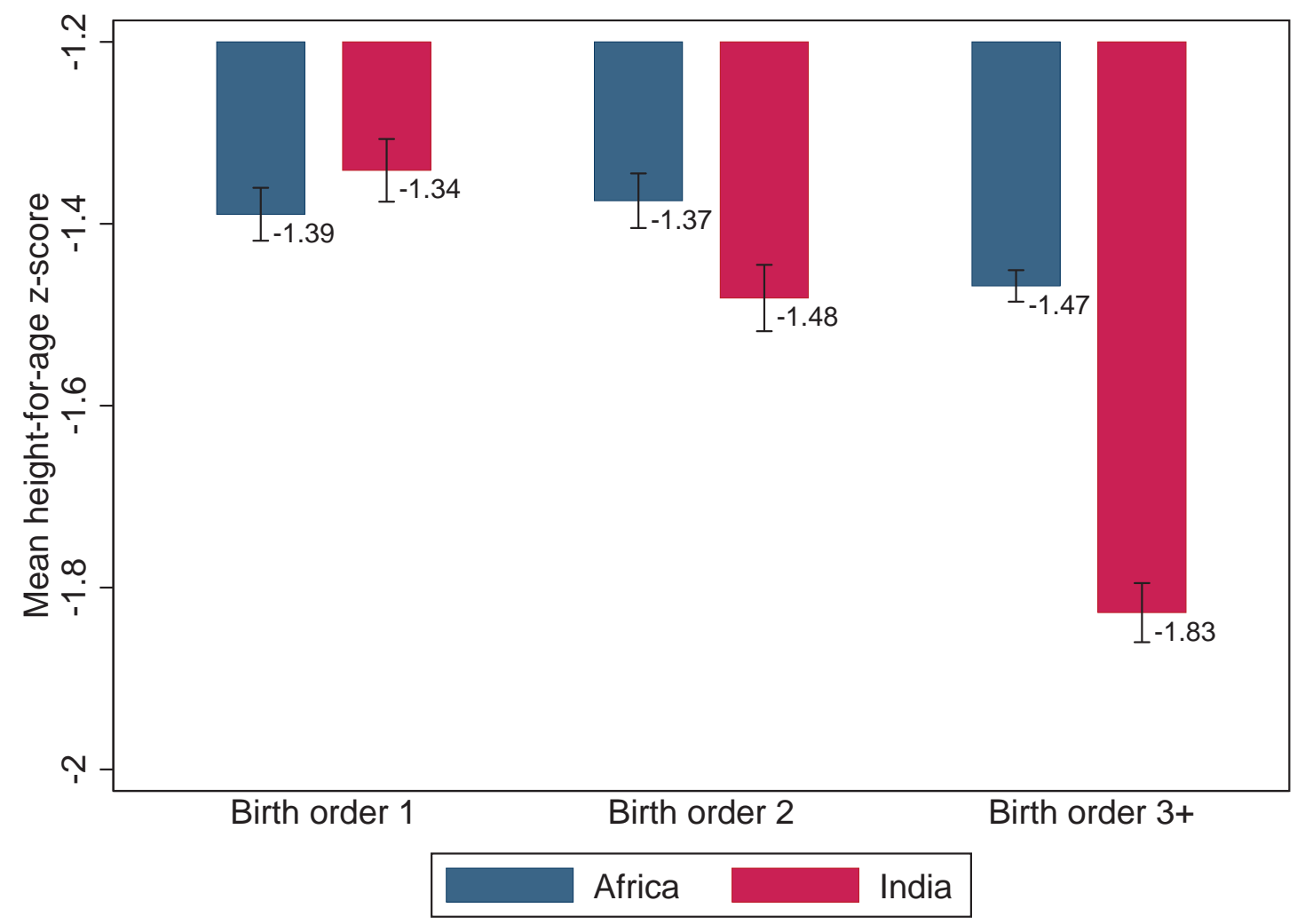

The figure depicts the mean child height-for-age z-scores for Sub-Saharan Africa and India, by the birth order of the child. The mean is calculated over all children less than 60 months old with anthropometric data. 
Table 1: Birth order gradient in the India height gap

\begin{tabular}{|c|c|c|c|c|c|c|}
\hline & $\begin{array}{c}\text { HFA z-score } \\
(1)\end{array}$ & $\begin{array}{c}\text { HFA z-score } \\
(2)\end{array}$ & $\begin{array}{c}\text { HFA z-score } \\
(3)\end{array}$ & $\begin{array}{c}\text { HFA z-score } \\
(4)\end{array}$ & $\begin{array}{c}\text { HFA z-score } \\
(5)\end{array}$ & $\begin{array}{c}\text { Stunted } \\
(6)\end{array}$ \\
\hline India & $\begin{array}{c}-0.110^{* * *} \\
{[0.014]}\end{array}$ & $\begin{array}{c}0.080^{* * *} \\
{[0.023]}\end{array}$ & & & & \\
\hline India $\times 2$ nd child & & $\begin{array}{c}-0.168^{* * *} \\
{[0.030]}\end{array}$ & $\begin{array}{c}-0.144^{* * *} \\
{[0.030]}\end{array}$ & $\begin{array}{c}-0.158^{* * *} \\
{[0.030]}\end{array}$ & $\begin{array}{c}-0.263^{* *} \\
{[0.110]}\end{array}$ & $\begin{array}{c}0.105^{* * *} \\
{[0.027]}\end{array}$ \\
\hline India $\times 3 r d+$ child & & $\begin{array}{c}-0.401^{* * *} \\
{[0.029]}\end{array}$ & $\begin{array}{c}-0.211^{* * *} \\
{[0.029]}\end{array}$ & $\begin{array}{c}-0.231^{* * *} \\
{[0.036]}\end{array}$ & $\begin{array}{c}-0.414^{* *} \\
{[0.193]}\end{array}$ & $\begin{array}{c}0.141^{* * *} \\
{[0.046]}\end{array}$ \\
\hline 2nd child & & $\begin{array}{l}0.038^{* *} \\
{[0.019]}\end{array}$ & $\begin{array}{c}0.067^{* * *} \\
{[0.019]}\end{array}$ & $\begin{array}{c}0.021 \\
{[0.019]}\end{array}$ & $\begin{array}{c}-0.208^{* * *} \\
{[0.066]}\end{array}$ & $\begin{array}{c}0.045^{* * *} \\
{[0.014]}\end{array}$ \\
\hline $3 r d+$ child & & $\begin{array}{c}-0.063^{* * *} \\
{[0.017]}\end{array}$ & $\begin{array}{c}0.057^{* * *} \\
{[0.017]}\end{array}$ & $\begin{array}{c}-0.106^{* * *} \\
{[0.021]}\end{array}$ & $\begin{array}{c}-0.465^{* * *} \\
{[0.106]}\end{array}$ & $\begin{array}{c}0.093^{* * *} \\
{[0.023]}\end{array}$ \\
\hline Africa mean of outcome & -1.435 & -1.435 & -1.435 & -1.435 & -1.435 & 0.390 \\
\hline HH covariates $\times$ India & No & No & Yes & Yes & No & No \\
\hline Child's age $\times$ India & No & No & No & Yes & Yes & Yes \\
\hline Mother's age at birth $\times$ India & No & No & No & Yes & No & No \\
\hline Mother FEs & No & No & No & No & Yes & Yes \\
\hline Observations & 174,157 & 174,157 & 174,157 & 174,157 & 174,157 & 174,157 \\
\hline
\end{tabular}

Notes: Standard errors are clustered by mother and appear in brackets. Asterisks denote significance: ${ }^{*} p<.10,{ }^{* *} p<.05,{ }^{* * *} p<.01$. HFA $z$-score is the child height-for-age z-score, and Stunted is defined as having an HFA z-score $\leq 2$. 2nd child is an indicator for children whose birth order is 2 . $3 r d+$ child is an indicator for children whose birth order is 3 or higher. Child age dummies are included in all columns, and survey month controls are included in Columns 1-4. Survey month controls are linear, quadratic and cubic terms for a continuous variable representing the month and year of the survey. In Columns 3-4, the main effect India is included in the regression but is not shown. In Columns 5-6, the main effect India is absorbed by child's age $\times$ India or a full set of mother fixed effects. Household covariates in Columns 3-4 include DHS wealth index, mother's literacy, rural, dummies for missing values of literacy, and household covariates $\times$ India. In Column 4 , a linear variable for mother's age at birth and mother's age at birth $\times$ India are included in the regression. See Data Appendix for further details. 
Table 2: Child health inputs

\begin{tabular}{|c|c|c|c|c|c|c|c|c|c|}
\hline & \multicolumn{4}{|c|}{ Prenatal inputs } & \multicolumn{3}{|c|}{ Postnatal inputs } & \multirow[b]{2}{*}{$\begin{array}{l}\text { Pooled } \\
\text { inputs } \\
(8)\end{array}$} & \multirow[b]{2}{*}{$\begin{array}{c}\text { Child's Hb } \\
\text { level } \\
\text { (9) }\end{array}$} \\
\hline & $\begin{array}{c}\text { Total } \\
\text { prenatal } \\
\text { visits } \\
(1)\end{array}$ & $\begin{array}{l}\text { Mother } \\
\text { took iron } \\
\text { supple- } \\
\text { ments } \\
(2)\end{array}$ & $\begin{array}{c}\text { Mother's } \\
\text { total } \\
\text { tetanus } \\
\text { shots } \\
(3)\end{array}$ & $\begin{array}{c}\text { Delivery at } \\
\text { health } \\
\text { facility } \\
\text { (4) }\end{array}$ & $\begin{array}{l}\text { Postnatal } \\
\text { check } \\
\text { within } 2 \\
\text { months } \\
(5)\end{array}$ & $\begin{array}{l}\text { Child } \\
\text { taking iron } \\
\text { pills } \\
(6)\end{array}$ & $\begin{array}{c}\text { Child's } \\
\text { total vacci- } \\
\text { nations } \\
(7)\end{array}$ & & \\
\hline India $\times 2$ nd child & $\begin{array}{c}-0.448^{* * *} \\
{[0.056]}\end{array}$ & $\begin{array}{l}-0.012 \\
{[0.008]}\end{array}$ & $\begin{array}{c}0.028 \\
{[0.017]}\end{array}$ & $\begin{array}{c}-0.035^{* * *} \\
{[0.006]}\end{array}$ & $\begin{array}{l}-0.010 \\
{[0.013]}\end{array}$ & $\begin{array}{l}-0.002 \\
{[0.005]}\end{array}$ & $\begin{array}{l}-0.073^{*} \\
{[0.042]}\end{array}$ & $\begin{array}{l}-0.005 \\
{[0.004]}\end{array}$ & $\begin{array}{c}-0.103^{* * *} \\
{[0.029]}\end{array}$ \\
\hline India $\times 3$ rd + child & $\begin{array}{c}-1.140^{* * *} \\
{[0.059]}\end{array}$ & $\begin{array}{c}-0.095^{* * *} \\
{[0.009]}\end{array}$ & $\begin{array}{c}0.009 \\
{[0.019]}\end{array}$ & $\begin{array}{c}-0.107^{* * *} \\
{[0.008]}\end{array}$ & $\begin{array}{c}0.012 \\
{[0.013]}\end{array}$ & $\begin{array}{c}0.003 \\
{[0.006]}\end{array}$ & $\begin{array}{c}-0.342^{* * *} \\
{[0.055]}\end{array}$ & $\begin{array}{c}-0.050^{* * *} \\
{[0.004]}\end{array}$ & $\begin{array}{c}-0.146^{* * *} \\
{[0.033]}\end{array}$ \\
\hline 2nd child & $\begin{array}{c}-0.123^{* * *} \\
{[0.031]}\end{array}$ & $\begin{array}{l}-0.005 \\
{[0.005]}\end{array}$ & $\begin{array}{c}-0.095^{* * *} \\
{[0.012]}\end{array}$ & $\begin{array}{c}-0.077^{* * *} \\
{[0.004]}\end{array}$ & $\begin{array}{l}0.020^{* *} \\
{[0.010]}\end{array}$ & $\begin{array}{l}-0.004 \\
{[0.004]}\end{array}$ & $\begin{array}{c}-0.064^{* *} \\
{[0.028]}\end{array}$ & $\begin{array}{c}-0.033^{* * *} \\
{[0.002]}\end{array}$ & $\begin{array}{l}-0.024 \\
{[0.021]}\end{array}$ \\
\hline 3rd + child & $\begin{array}{c}-0.536^{* * *} \\
{[0.032]}\end{array}$ & $\begin{array}{c}-0.014^{* * *} \\
{[0.005]}\end{array}$ & $\begin{array}{c}-0.204^{* * *} \\
{[0.013]}\end{array}$ & $\begin{array}{c}-0.143^{* * *} \\
{[0.004]}\end{array}$ & $\begin{array}{c}-0.019^{* *} \\
{[0.010]}\end{array}$ & $\begin{array}{c}-0.022^{* * *} \\
{[0.005]}\end{array}$ & $\begin{array}{c}-0.378^{* * *} \\
{[0.032]}\end{array}$ & $\begin{array}{c}-0.079^{* * *} \\
{[0.003]}\end{array}$ & $\begin{array}{c}-0.101^{* * *} \\
{[0.023]}\end{array}$ \\
\hline Africa mean of outcome & 3.828 & 0.617 & 1.406 & 0.469 & 0.293 & 0.112 & 6.187 & 0.627 & 10.145 \\
\hline India mean of outcome & 4.031 & 0.687 & 1.867 & 0.449 & 0.090 & 0.055 & 6.593 & 0.754 & 10.271 \\
\hline Household \& age controls & Yes & Yes & Yes & Yes & Yes & Yes & Yes & Yes & Yes \\
\hline Observations & 120,570 & 122,977 & 122,530 & 173,772 & 39,248 & 95,986 & 127,544 & 802,627 & 91,505 \\
\hline
\end{tabular}

Notes: Standard errors are clustered by mother and appear in brackets. Asterisks denote significance: $* p<.10, * * p<.05, * * * p<.01$. Control variables included are survey month controls, child age dummies, household covariates, mother's age at birth, and household covariates, child's age, and mother's age interacted with India. The main effect India is included in all regressions but is not shown. Total prenatal visits, mother took iron supplements, mother's total tetanus shots, and postnatal check within 2 months are only available for the youngest living child in the family; postnatal check within 2 months is collected in only 13 African surveys. Delivery at health facility, child taking iron pills, and total vaccinations are available for all births in the past 5 years; child taking iron pills is collected in only 10 African surveys; total vaccinations is only available for children ages 13-59 months. In Column 8, dummies for 4 prenatal and 3 postnatal inputs are pooled together to create the outcome. The dummies are: 1 ) total prenatal visits $>4 ; 2$ ) mother took iron supplements; 3) mother's total tetanus shots $>1 ; 4$ ) child was delivered at a health facility; 5) child is taking iron pills; 6) total vaccinations $>7 ; 7$ ) child had postnatal check within 2 months of birth. See Data Appendix for further details. 
Table 3: Child gender and the birth order gradient in height

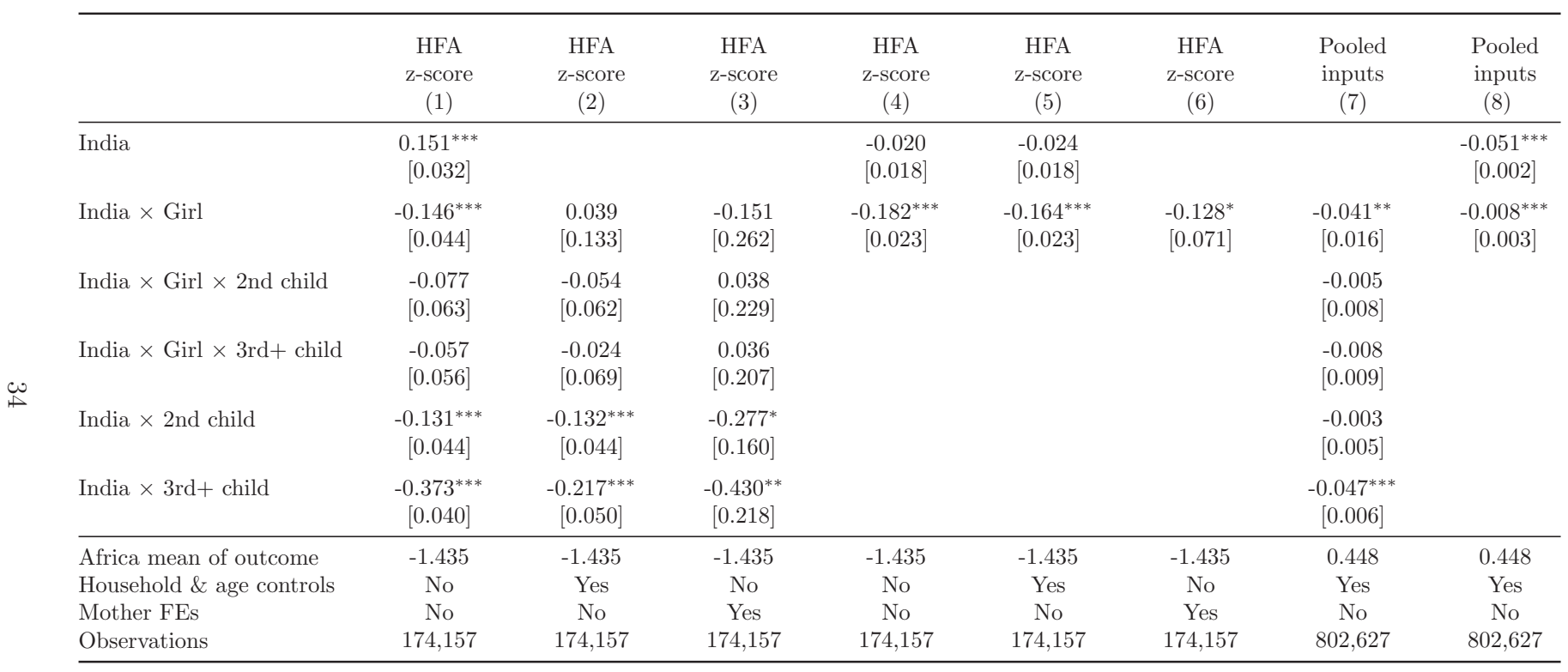

Notes: Standard errors are clustered by household and appear in brackets. Asterisks denote significance: $* p<.10, * * p<.05, * * * p<.01$. Child age dummies are included in all regressions, and all columns control for survey month except for Columns 3 and 6 , which have mother fixed effects. Columns 2, 5, 7, and 8 additionally include household covariates and mother's age. Columns 2 and 7 have household covariates, child's age, and mother's age interacted with Girl, India, and Girl $\times$ India. The main effect India is included in Columns 2 and 7 but is not shown. In Columns 1-3 and 7, coefficients for Girl, 2nd child and 3rd + child birth order dummies, the birth order dummies $\times$ Girl are included in the regression but are not shown. In Columns 4-6 and 8, the main effect Girl is included in the regression but is not shown. 
Table 4: Heterogeneity within India by son preference

\begin{tabular}{|c|c|c|c|c|c|c|}
\hline \multirow[t]{2}{*}{ Gender preference proxy: } & Muslim & Kerala & $\begin{array}{l}\text { Below-median } \\
\text { child sex ratio }\end{array}$ & Muslim & Kerala & $\begin{array}{l}\text { Below-median } \\
\text { child sex ratio }\end{array}$ \\
\hline & $\begin{array}{c}\text { HFA z-score } \\
(1)\end{array}$ & $\begin{array}{c}\text { HFA z-score } \\
(2)\end{array}$ & $\begin{array}{l}\text { HFA z-score } \\
\quad(3)\end{array}$ & $\begin{array}{l}\text { Pooled inputs } \\
\quad(4)\end{array}$ & $\begin{array}{l}\text { Pooled inputs } \\
\quad(5)\end{array}$ & $\begin{array}{c}\text { Pooled inputs } \\
\quad(6)\end{array}$ \\
\hline Gender pref proxy $\times 2$ nd child & $\begin{array}{l}0.147^{* *} \\
{[0.067]}\end{array}$ & $\begin{array}{l}0.223^{*} \\
{[0.132]}\end{array}$ & $\begin{array}{c}0.062 \\
{[0.046]}\end{array}$ & $\begin{array}{c}0.007 \\
{[0.008]}\end{array}$ & $\begin{array}{c}0.042^{* * *} \\
{[0.009]}\end{array}$ & $\begin{array}{l}0.011^{* *} \\
{[0.005]}\end{array}$ \\
\hline Gender pref proxy $\times$ 3rd + child & $\begin{array}{l}0.203^{* *} \\
{[0.081]}\end{array}$ & $\begin{array}{c}0.249 \\
{[0.206]}\end{array}$ & $\begin{array}{c}0.001 \\
{[0.057]}\end{array}$ & $\begin{array}{c}0.032^{* * *} \\
{[0.009]}\end{array}$ & $\begin{array}{c}0.081^{* * *} \\
{[0.014]}\end{array}$ & $\begin{array}{l}-0.001 \\
{[0.007]}\end{array}$ \\
\hline 2nd child & $\begin{array}{c}-0.153^{* * *} \\
{[0.027]}\end{array}$ & $\begin{array}{c}-0.138^{* * *} \\
{[0.023]}\end{array}$ & $\begin{array}{c}-0.164^{* * *} \\
{[0.033]}\end{array}$ & $\begin{array}{c}-0.030^{* * *} \\
{[0.003]}\end{array}$ & $\begin{array}{c}-0.030^{* * *} \\
{[0.003]}\end{array}$ & $\begin{array}{c}-0.034^{* * *} \\
{[0.004]}\end{array}$ \\
\hline 3rd + child & $\begin{array}{c}-0.363^{* * *} \\
{[0.033]}\end{array}$ & $\begin{array}{c}-0.325^{* * *} \\
{[0.029]}\end{array}$ & $\begin{array}{c}-0.304^{* * *} \\
{[0.041]}\end{array}$ & $\begin{array}{c}-0.117^{* * *} \\
{[0.004]}\end{array}$ & $\begin{array}{c}-0.117^{* * *} \\
{[0.003]}\end{array}$ & $\begin{array}{c}-0.113^{* * *} \\
{[0.005]}\end{array}$ \\
\hline $\begin{aligned} \text { p-value: Gender pref proxy } \times 2 \text { nd child } \\
\\
+2 \text { nd child }=0\end{aligned}$ & 0.934 & 0.514 & 0.002 & 0.001 & 0.182 & 0.000 \\
\hline $\begin{aligned} \text { p-value: } & \text { Gender pref proxy } \times 3 \mathrm{rd}+\text { child } \\
& +3 \mathrm{rd}+\text { child }=0\end{aligned}$ & 0.031 & 0.710 & 0.000 & 0.000 & 0.010 & 0.000 \\
\hline Sample & $\begin{array}{l}\text { Hindus \& } \\
\text { Muslims }\end{array}$ & India & India & $\begin{array}{l}\text { Hindus \& } \\
\text { Muslims }\end{array}$ & India & India \\
\hline Household \& age controls & Yes & Yes & Yes & Yes & Yes & Yes \\
\hline Observations & 36,657 & 43,043 & 43,043 & 214,400 & 250,702 & 250,702 \\
\hline
\end{tabular}

Notes: Standard errors are clustered by mother and appear in brackets. Asterisks denote significance: ${ }^{*} p<.10,{ }^{* *} p<.05, * * * p<.01$. The sample is restricted to India and control variables included in all columns are survey month controls, child age dummies, household covariates, mother's age, and household covariates, child's age, and mother's age $\times$ Gender pref proxy. The main effect Gender pref proxy is included in all regressions but is not shown. Child sex ratio is defined as the number of boys aged 0-6 years over the number of girls aged 0-6 years in the respondent's state-by-rural cell. See Data Appendix for further details. 
Table 5: Heterogeneity by the gender of older siblings

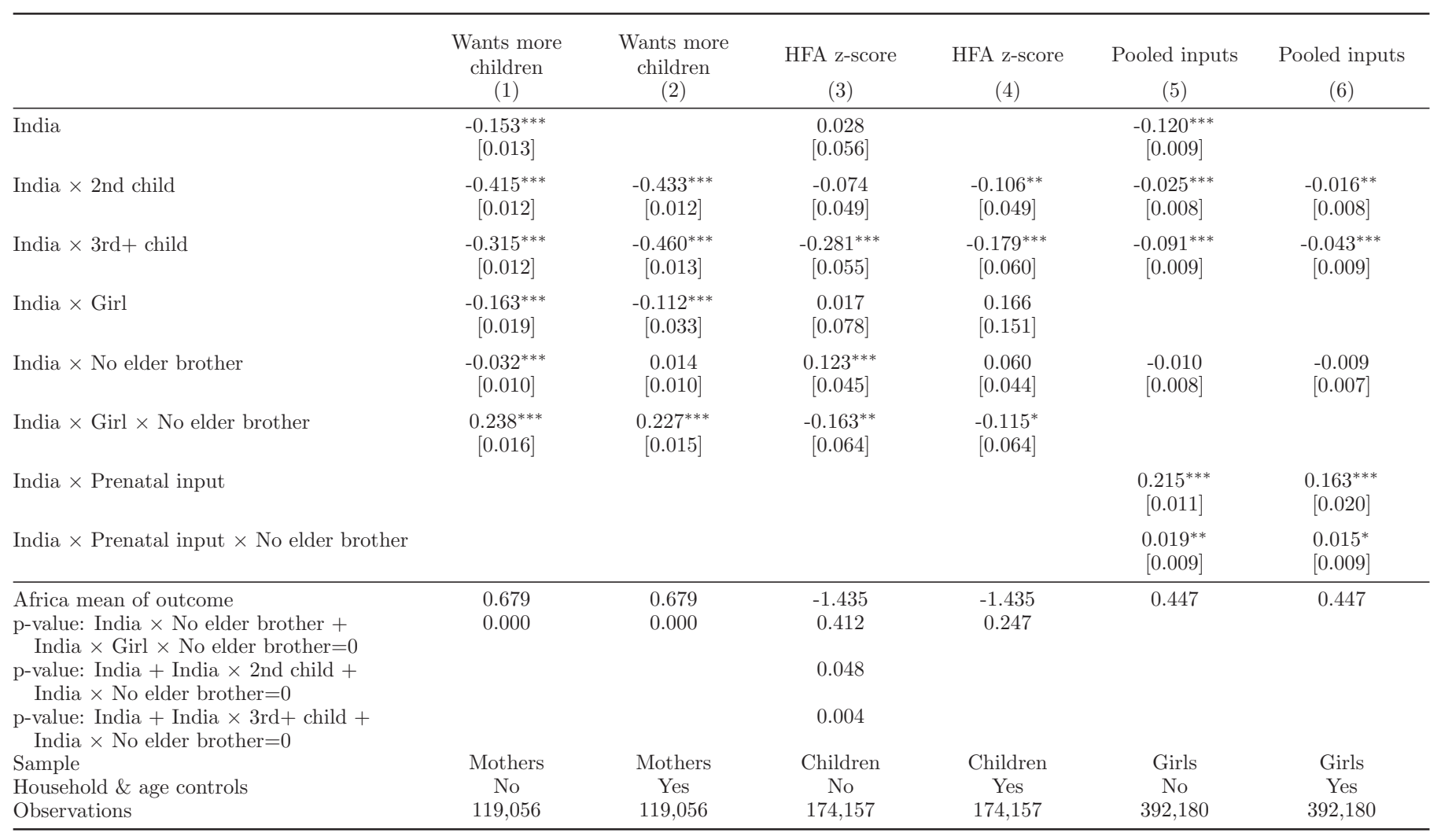

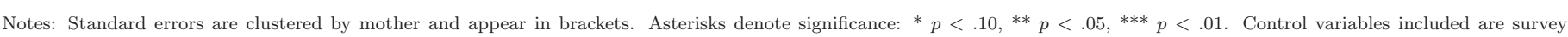

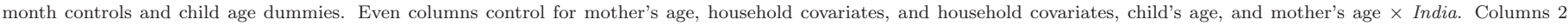

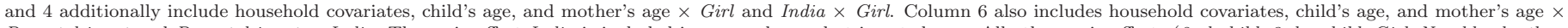

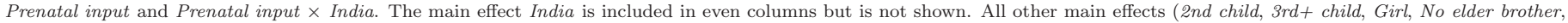

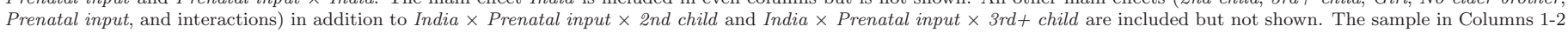

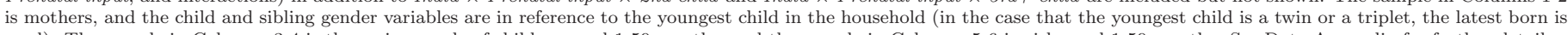

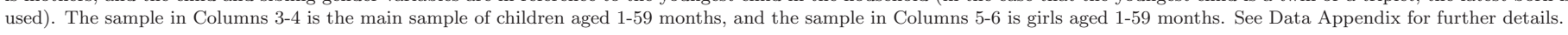


Appendix Table 1: Summary statistics

\begin{tabular}{|c|c|c|c|c|c|}
\hline & $\begin{array}{c}\text { India } \\
\text { subsample }\end{array}$ & $\begin{array}{c}\text { Africa } \\
\text { subsample }\end{array}$ & & $\begin{array}{c}\text { India } \\
\text { subsample }\end{array}$ & $\begin{array}{c}\text { Africa } \\
\text { subsample }\end{array}$ \\
\hline Mother's age at birth (years) & $\begin{array}{l}24.767 \\
{[5.239]}\end{array}$ & $\begin{array}{l}26.954 \\
{[6.857]}\end{array}$ & Child's age (months) & $\begin{array}{c}30.051 \\
{[16.872]}\end{array}$ & $\begin{array}{c}28.062 \\
{[17.026]}\end{array}$ \\
\hline Mother's total children born & $\begin{array}{c}2.745 \\
{[1.829]}\end{array}$ & $\begin{array}{c}3.876 \\
{[2.543]}\end{array}$ & Child is a girl & $\begin{array}{c}0.465 \\
{[0.499]}\end{array}$ & $\begin{array}{c}0.494 \\
{[0.500]}\end{array}$ \\
\hline Preceding birth interval (months) & $\begin{array}{c}36.333 \\
{[21.431]}\end{array}$ & $\begin{array}{c}38.962 \\
{[22.247]}\end{array}$ & Child's birth order & $\begin{array}{c}2.625 \\
{[1.808]}\end{array}$ & $\begin{array}{c}3.742 \\
{[2.477]}\end{array}$ \\
\hline Total prenatal visits & $\begin{array}{c}4.031 \\
{[3.483]}\end{array}$ & $\begin{array}{c}3.828 \\
{[3.095]}\end{array}$ & Child's HFA z-score & $\begin{array}{l}-1.575 \\
{[2.114]}\end{array}$ & $\begin{array}{l}-1.435 \\
{[2.466]}\end{array}$ \\
\hline Mother took iron supplements & $\begin{array}{c}0.687 \\
{[0.464]}\end{array}$ & $\begin{array}{c}0.617 \\
{[0.486]}\end{array}$ & Child is stunted & $\begin{array}{c}0.414 \\
{[0.493]}\end{array}$ & $\begin{array}{c}0.390 \\
{[0.488]}\end{array}$ \\
\hline Mother's total tetanus shots & $\begin{array}{c}1.867 \\
{[0.941]}\end{array}$ & $\begin{array}{c}1.406 \\
{[1.202]}\end{array}$ & Child's hemoglobin level (g/dl) & $\begin{array}{l}10.271 \\
{[1.568]}\end{array}$ & $\begin{array}{l}10.145 \\
{[1.680]}\end{array}$ \\
\hline Delivery at health facility & $\begin{array}{c}0.449 \\
{[0.497]}\end{array}$ & $\begin{array}{c}0.469 \\
{[0.499]}\end{array}$ & Child is deceased & $\begin{array}{c}0.050 \\
{[0.217]}\end{array}$ & $\begin{array}{c}0.072 \\
{[0.259]}\end{array}$ \\
\hline Postnatal check within 2 months & $\begin{array}{c}0.090 \\
{[0.287]}\end{array}$ & $\begin{array}{c}0.293 \\
{[0.455]}\end{array}$ & Child taking iron pills & $\begin{array}{c}0.055 \\
{[0.228]}\end{array}$ & $\begin{array}{c}0.112 \\
{[0.315]}\end{array}$ \\
\hline Mother is literate & $\begin{array}{c}0.584 \\
{[0.493]}\end{array}$ & $\begin{array}{c}0.492 \\
{[0.500]}\end{array}$ & Child's total vaccinations & $\begin{array}{c}6.746 \\
{[2.744]}\end{array}$ & $\begin{array}{c}6.296 \\
{[3.108]}\end{array}$ \\
\hline DHS wealth index & $\begin{array}{l}-0.219 \\
{[0.949]}\end{array}$ & $\begin{array}{l}-0.145 \\
{[0.928]}\end{array}$ & Diarrhea in last 2 weeks & $\begin{array}{c}0.095 \\
{[0.293]}\end{array}$ & $\begin{array}{c}0.157 \\
{[0.364]}\end{array}$ \\
\hline Rural & $\begin{array}{c}0.632 \\
{[0.482]}\end{array}$ & $\begin{array}{c}0.719 \\
{[0.449]}\end{array}$ & Open defecation & $\begin{array}{c}0.456 \\
{[0.498]}\end{array}$ & $\begin{array}{c}0.322 \\
{[0.467]}\end{array}$ \\
\hline Mother wants more children & $\begin{array}{c}0.336 \\
{[0.473]}\end{array}$ & $\begin{array}{c}0.679 \\
{[0.467]}\end{array}$ & $\%$ non-resident among children & $\begin{array}{c}0.023 \\
{[0.039]}\end{array}$ & $\begin{array}{c}0.098 \\
{[0.086]}\end{array}$ \\
\hline Mother's height (meters) & $\begin{array}{c}1.519 \\
{[0.058]}\end{array}$ & $\begin{array}{c}1.583 \\
{[0.069]}\end{array}$ & Land scarcity & $\begin{array}{c}5.035 \\
-\end{array}$ & $\begin{array}{c}2.617 \\
{[1.143]}\end{array}$ \\
\hline Mother's hemoglobin level (g/dl) & $\begin{array}{l}11.582 \\
{[1.731]}\end{array}$ & $\begin{array}{l}12.023 \\
{[1.829]}\end{array}$ & Child sex ratio (boys/girls) & $\begin{array}{c}1.079 \\
{[0.051]}\end{array}$ & $\begin{array}{l}- \\
- \\
-\end{array}$ \\
\hline Mother's consumption index (non-pregnant) & $\begin{array}{l}1.924 \\
{[1.096]}\end{array}$ & $\begin{array}{c}2.246 \\
{[1.331]}\end{array}$ & Log GDP per capita (in child's birth year) & $\begin{array}{c}7.735 \\
{[0.125]}\end{array}$ & $\begin{array}{c}6.891 \\
{[0.653]}\end{array}$ \\
\hline \multirow[t]{2}{*}{ Mother's consumption index (pregnant) } & $\begin{array}{c}1.861 \\
{[1.085]}\end{array}$ & $\begin{array}{c}2.265 \\
{[1.302]}\end{array}$ & Main sample of children $<60$ months $(\mathrm{N})$ & 43,043 & 131,114 \\
\hline & & & Children with siblings in main sample $(\mathrm{N})$ & 20,054 & 68,209 \\
\hline
\end{tabular}

Notes: The means of the specified variables are calculated separately for the India and Africa subsamples. Standard deviations appear in brackets. The following variables are summarized at the mother level: total children born, mother is literate, wants more children, mother's height, hemoglobin level, and consumption index (non-pregnant and pregnant). Total prenatal visits, mother took iron supplements, total tetanus shots, postnatal check within 2 months are also, in effect, summarized at the mother level because they are only available for the most recent birth. Variables summarized at the child level include: mother's age at birth, preceding birth interval, delivery at health facility, DHS wealth index, rural, all child variables (first 9 variables in the second column), diarrhea in last 2 weeks, open defecation, \% non-resident among children, land scarcity, child sex ratio, and log GDP. 
Appendix Table 2: Birth order gradient in the India height gap: Robustness checks

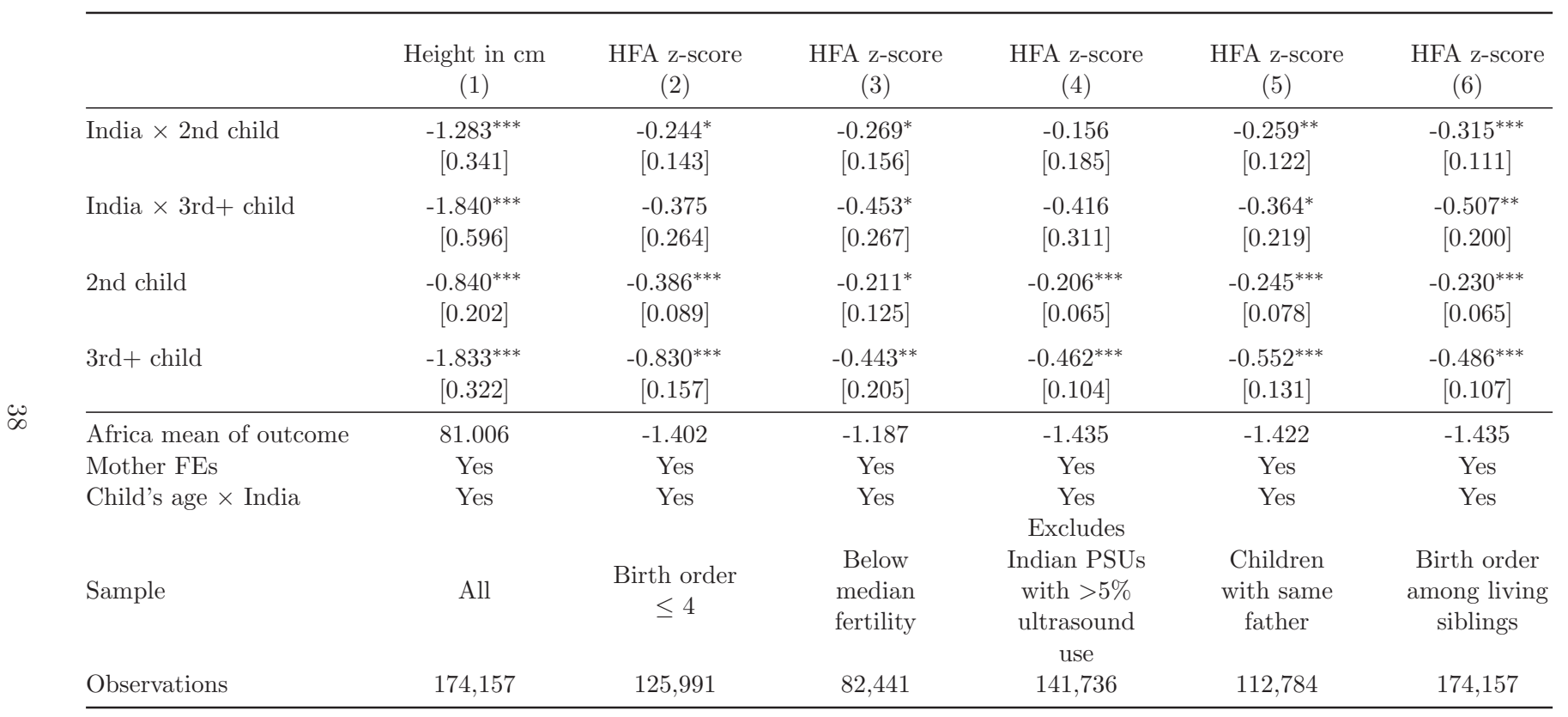

Notes: Standard errors are clustered by mother and appear in brackets. Asterisks denote significance: $* p<.10, * * p<.05, * * * p<.01$. Control variables included are child age dummies and child's age $\times$ India. The main effect India is absorbed by child age's $\times$ India or a full set of mother fixed effects. In Columns 2-5, the sample restrictions are as follows: children of birth order 4 or less; children from African countries with below median fertility, plus India; children in Indian PSUs where less than 5\% of mothers reported using ultrasound during pregnancy, plus Africa; children whose mothers (likely) had children with only one partner. In Column 6, birth order is redefined as the birth order among currently living siblings. See Data Appendix for further details. 
Appendix Table 3: Using other comparison groups: Countries with similar GDP to India, and Europe, Central \& West Asia

\begin{tabular}{|c|c|c|c|c|c|c|}
\hline \multirow[t]{2}{*}{ Comparison sample: } & \multicolumn{3}{|c|}{ Countries with similar GDP to India } & \multicolumn{3}{|c|}{ Europe, Central \& West Asia } \\
\hline & $\begin{array}{c}\text { HFA z-score } \\
\text { (1) }\end{array}$ & $\begin{array}{c}\text { HFA z-score } \\
(2)\end{array}$ & $\begin{array}{c}\text { HFA z-score } \\
(3)\end{array}$ & $\begin{array}{c}\text { HFA z-score } \\
(4)\end{array}$ & $\begin{array}{c}\text { HFA z-score } \\
(5)\end{array}$ & $\begin{array}{c}\text { HFA z-score } \\
(6)\end{array}$ \\
\hline India & $\begin{array}{l}-0.003 \\
{[0.023]}\end{array}$ & & & $\begin{array}{c}-0.884^{* * *} \\
{[0.028]}\end{array}$ & & \\
\hline India $\times$ 2nd child & $\begin{array}{c}-0.115^{* * *} \\
{[0.030]}\end{array}$ & $\begin{array}{c}-0.107^{* * *} \\
{[0.030]}\end{array}$ & $\begin{array}{c}-0.265^{* *} \\
{[0.111]}\end{array}$ & $\begin{array}{c}-0.055^{*} \\
{[0.033]}\end{array}$ & $\begin{array}{l}-0.034 \\
{[0.033]}\end{array}$ & $\begin{array}{c}-0.259^{* *} \\
{[0.121]}\end{array}$ \\
\hline India $\times 3 \mathrm{rd}+$ child & $\begin{array}{c}-0.311^{* * *} \\
{[0.028]}\end{array}$ & $\begin{array}{c}-0.152^{* * *} \\
{[0.035]}\end{array}$ & $\begin{array}{c}-0.463^{* *} \\
{[0.196]}\end{array}$ & $\begin{array}{c}-0.305^{* * *} \\
{[0.032]}\end{array}$ & $\begin{array}{c}-0.120^{* * *} \\
{[0.039]}\end{array}$ & $\begin{array}{c}-0.627^{* * *} \\
{[0.224]}\end{array}$ \\
\hline 2nd child & $\begin{array}{l}-0.016 \\
{[0.019]}\end{array}$ & $\begin{array}{l}-0.031 \\
{[0.019]}\end{array}$ & $\begin{array}{c}-0.203^{* * *} \\
{[0.067]}\end{array}$ & $\begin{array}{c}-0.078^{* * *} \\
{[0.023]}\end{array}$ & $\begin{array}{c}-0.105^{* * *} \\
{[0.024]}\end{array}$ & $\begin{array}{c}-0.231^{* * *} \\
{[0.080]}\end{array}$ \\
\hline $3 r d+$ child & $\begin{array}{c}-0.154^{* * *} \\
{[0.016]} \\
\end{array}$ & $\begin{array}{c}-0.186^{* * *} \\
{[0.021]}\end{array}$ & $\begin{array}{c}-0.414^{* * *} \\
{[0.110]}\end{array}$ & $\begin{array}{c}-0.162^{* * *} \\
{[0.022]} \\
\end{array}$ & $\begin{array}{c}-0.216^{* * *} \\
{[0.027]} \\
\end{array}$ & $\begin{array}{c}-0.296^{* *} \\
{[0.150]}\end{array}$ \\
\hline Comparison group mean of outcome & -1.390 & -1.390 & -1.390 & -0.595 & -0.595 & -0.595 \\
\hline HH covariates $\times$ India & No & Yes & No & No & Yes & No \\
\hline Child's age $\times$ India & No & Yes & Yes & No & Yes & Yes \\
\hline Mother's age at birth $\times$ India & No & Yes & No & No & Yes & No \\
\hline Mother FEs & No & No & Yes & No & No & Yes \\
\hline Observations & 172,065 & 172,065 & 172,065 & 85,553 & 85,553 & 85,553 \\
\hline
\end{tabular}

Notes: Standard errors are clustered by mother and appear in brackets. Asterisks denote significance: $* p<.10, * * p<.05, * * * p<.01$. Child age dummies are included in all regressions, and all columns include survey month controls, except for Columns 3 and 6 , which have mother fixed effects. The main effect India is included but not shown in Columns 2 \& 5. In Columns 1-3, the omitted category includes 23 DHS's (2004-2010) of countries with height data that had a log GDP per capita within in a 50\% upper and lower bound of India's 2005-6 log GDP per capita in its survey year. In Columns 4-6, the omitted category includes 16 DHS's (1995-2012) of European, Central and West Asian countries with height data available. In Column 5, we use mother completed grade 4 or higher as a control instead of mother's literacy due to the large amount if missing data for mother's literacy in the the Europe, Central \& West Asia sample. Completion of grade 4 or higher is recoded as 0 if mother's literacy is available in the data and she is illiterate. 
Appendix Table 4: Heterogeneity by older siblings' gender: Robustness to sex-selection

\begin{tabular}{|c|c|c|c|c|c|c|c|c|c|c|}
\hline \multirow[t]{2}{*}{ Sample: } & \multicolumn{2}{|c|}{ Illiterate } & \multicolumn{2}{|c|}{ Literate } & \multicolumn{2}{|c|}{ Rural } & \multicolumn{2}{|c|}{ Urban } & \multicolumn{2}{|c|}{$\begin{array}{c}\text { Excludes Indian } \\
\text { PSUs with }>5 \% \\
\text { ultrasound use }\end{array}$} \\
\hline & $\begin{array}{c}\text { HFA } \\
\text { z-score } \\
(1)\end{array}$ & $\begin{array}{c}\text { HFA } \\
\text { z-score } \\
(2)\end{array}$ & $\begin{array}{c}\text { HFA } \\
\text { z-score } \\
(3)\end{array}$ & $\begin{array}{c}\text { HFA } \\
\text { z-score } \\
(4)\end{array}$ & $\begin{array}{c}\text { HFA } \\
\text { z-score } \\
(5)\end{array}$ & $\begin{array}{c}\text { HFA } \\
\text { z-score } \\
(6)\end{array}$ & $\begin{array}{c}\text { HFA } \\
\text { z-score } \\
(7)\end{array}$ & $\begin{array}{c}\text { HFA } \\
\text { z-score } \\
(8)\end{array}$ & $\begin{array}{c}\text { HFA } \\
\text { z-score } \\
(9)\end{array}$ & $\begin{array}{c}\text { HFA } \\
\text { z-score } \\
(10)\end{array}$ \\
\hline India & $\begin{array}{c}-0.236^{* * *} \\
{[0.090]}\end{array}$ & & $\begin{array}{c}0.038 \\
{[0.072]}\end{array}$ & & $\begin{array}{c}0.012 \\
{[0.069]}\end{array}$ & & $\begin{array}{l}-0.120 \\
{[0.096]}\end{array}$ & & $\begin{array}{c}-0.416^{* * *} \\
{[0.101]}\end{array}$ & \\
\hline India $\times$ 2nd child & $\begin{array}{l}-0.005 \\
{[0.082]}\end{array}$ & $\begin{array}{l}-0.027 \\
{[0.082]}\end{array}$ & $\begin{array}{l}-0.083 \\
{[0.062]}\end{array}$ & $\begin{array}{c}-0.139^{* *} \\
{[0.062]}\end{array}$ & $\begin{array}{c}0.009 \\
{[0.062]}\end{array}$ & $\begin{array}{l}-0.012 \\
{[0.062]}\end{array}$ & $\begin{array}{c}-0.209^{* * *} \\
{[0.081]}\end{array}$ & $\begin{array}{c}-0.248^{* * *} \\
{[0.082]}\end{array}$ & $\begin{array}{c}0.066 \\
{[0.093]}\end{array}$ & $\begin{array}{c}0.041 \\
{[0.093]}\end{array}$ \\
\hline India $\times 3$ rd + child & $\begin{array}{l}-0.076 \\
{[0.088]}\end{array}$ & $\begin{array}{l}-0.059 \\
{[0.094]}\end{array}$ & $\begin{array}{c}-0.228^{* * *} \\
{[0.072]}\end{array}$ & $\begin{array}{c}-0.223^{* * *} \\
{[0.079]}\end{array}$ & $\begin{array}{c}-0.200^{* * *} \\
{[0.068]}\end{array}$ & $\begin{array}{l}-0.096 \\
{[0.074]}\end{array}$ & $\begin{array}{c}-0.425^{* * *} \\
{[0.095]}\end{array}$ & $\begin{array}{c}-0.284^{* * *} \\
{[0.105]}\end{array}$ & $\begin{array}{c}0.018 \\
{[0.099]}\end{array}$ & $\begin{array}{c}0.041 \\
{[0.108]}\end{array}$ \\
\hline India $\times$ Girl & $\begin{array}{c}0.036 \\
{[0.124]}\end{array}$ & $\begin{array}{c}0.240 \\
{[0.226]}\end{array}$ & $\begin{array}{l}-0.008 \\
{[0.100]}\end{array}$ & $\begin{array}{c}0.139 \\
{[0.198]}\end{array}$ & $\begin{array}{c}0.019 \\
{[0.096]}\end{array}$ & $\begin{array}{l}-0.003 \\
{[0.183]}\end{array}$ & $\begin{array}{l}-0.002 \\
{[0.134]}\end{array}$ & $\begin{array}{c}0.412 \\
{[0.255]}\end{array}$ & $\begin{array}{c}0.113 \\
{[0.140]}\end{array}$ & $\begin{array}{c}0.102 \\
{[0.281]}\end{array}$ \\
\hline India $\times$ No elder brother & $\begin{array}{c}0.070 \\
{[0.068]}\end{array}$ & $\begin{array}{c}0.039 \\
{[0.069]}\end{array}$ & $\begin{array}{l}0.136^{* *} \\
{[0.059]}\end{array}$ & $\begin{array}{c}0.092 \\
{[0.058]}\end{array}$ & $\begin{array}{c}0.130^{* *} \\
{[0.055]}\end{array}$ & $\begin{array}{c}0.057 \\
{[0.054]}\end{array}$ & $\begin{array}{c}0.113 \\
{[0.079]}\end{array}$ & $\begin{array}{c}0.059 \\
{[0.078]}\end{array}$ & $\begin{array}{c}0.040 \\
{[0.081]}\end{array}$ & $\begin{array}{c}0.025 \\
{[0.081]}\end{array}$ \\
\hline India $\times$ Girl $\times$ No elder brother & $\begin{array}{l}-0.152 \\
{[0.097]}\end{array}$ & $\begin{array}{l}-0.142 \\
{[0.098]}\end{array}$ & $\begin{array}{c}-0.155^{*} \\
{[0.086]}\end{array}$ & $\begin{array}{l}-0.111 \\
{[0.085]}\end{array}$ & $\begin{array}{c}-0.157^{* *} \\
{[0.078]} \\
\end{array}$ & $\begin{array}{l}-0.102 \\
{[0.077]}\end{array}$ & $\begin{array}{l}-0.155 \\
{[0.114]}\end{array}$ & $\begin{array}{l}-0.146 \\
{[0.113]}\end{array}$ & $\begin{array}{c}-0.260^{* *} \\
{[0.113]}\end{array}$ & $\begin{array}{c}-0.244^{* *} \\
{[0.112]} \\
\end{array}$ \\
\hline Africa mean of outcome & -1.602 & -1.602 & -1.250 & -1.250 & -1.582 & -1.582 & -1.057 & -1.057 & -1.435 & -1.435 \\
\hline $\begin{array}{l}\text { p-value: India } \times \text { No elder brother }+ \\
\quad \text { India } \times \text { Girl } \times \text { No elder brother }=0\end{array}$ & 0.254 & 0.154 & 0.775 & 0.764 & 0.632 & 0.424 & 0.625 & 0.299 & 0.008 & 0.007 \\
\hline $\begin{array}{l}\text { p-value: India }+ \text { India } \times 2 \text { nd child }+ \\
\quad \text { India } \times \text { No elder brother }=0\end{array}$ & 0.007 & & 0.068 & & 0.002 & & 0.001 & & 0.000 & \\
\hline $\begin{array}{l}\text { p-value: India }+ \text { India } \times 3 \mathrm{rd}+\text { child }+ \\
\quad \text { India } \times \text { No elder brother }=0\end{array}$ & 0.000 & & 0.382 & & 0.290 & & 0.000 & & 0.000 & \\
\hline Household \& age controls & No & Yes & No & Yes & No & Yes & No & Yes & No & Yes \\
\hline Observations & 86,752 & 86,752 & 86,113 & 86,113 & 121,474 & 121,474 & 52,683 & 52,683 & 141,736 & 141,736 \\
\hline
\end{tabular}

Notes: Standard errors are clustered by mother and appear in brackets. Asterisks denote significance: $* p<.10,{ }^{* *} p<.05,{ }^{* * *} p<.01$. Control variables included are survey month controls and child age dummies. All columns include birth order dummies and birth order dummies interacted with Girl and India $\times$ Girl. Even columns additionally control for mother's age at birth, household covariates, and household covariates, child's age, and mother's age interacted with India, Girl, and India $\times$ Girl. Columns 2 and 4 omit literacy covariates and Columns 6 and 8 omit rural covariates. The main effect India is included in even columns but is not shown. All other main effects (birth order dummies, Girl, No elder brother, and interactions) are included but not reported. The sample for Columns 9-10 includes Indian children living in PSUs with a mean ultrasound usage of $<5 \%$ and Africa. 
Appendix Table 5: Alternative explanations for the Indian birth order gradient

\begin{tabular}{|c|c|c|c|c|c|c|}
\hline & $\begin{array}{l}\text { Deceased } \\
\quad(1)\end{array}$ & $\begin{array}{c}\text { HFA z-score } \\
(2)\end{array}$ & $\begin{array}{c}\text { Diarrhea in last } \\
2 \text { weeks } \\
(3)\end{array}$ & $\begin{array}{l}\text { HFA z-score } \\
\quad(4)\end{array}$ & $\begin{array}{c}\text { HFA z-score } \\
(5)\end{array}$ & $\begin{array}{l}\text { HFA z-score } \\
\quad(6)\end{array}$ \\
\hline India $\times 2$ nd child & $\begin{array}{l}0.006^{*} \\
{[0.003]}\end{array}$ & $\begin{array}{c}-0.144^{* * *} \\
{[0.033]}\end{array}$ & $\begin{array}{c}0.002 \\
{[0.005]}\end{array}$ & $\begin{array}{c}-0.172^{* * *} \\
{[0.031]}\end{array}$ & $\begin{array}{c}-0.134^{* * *} \\
{[0.034]}\end{array}$ & $\begin{array}{c}-0.178^{* * *} \\
{[0.055]}\end{array}$ \\
\hline India $\times 3$ rd + child & $\begin{array}{c}0.011^{* * *} \\
{[0.004]}\end{array}$ & $\begin{array}{c}-0.197^{* * *} \\
{[0.039]}\end{array}$ & $\begin{array}{l}0.011^{* *} \\
{[0.005]}\end{array}$ & $\begin{array}{c}-0.237^{* * *} \\
{[0.037]}\end{array}$ & $\begin{array}{c}-0.206^{* * *} \\
{[0.040]}\end{array}$ & $\begin{array}{c}-0.220^{* * *} \\
{[0.061]}\end{array}$ \\
\hline 2nd child & $\begin{array}{c}-0.019^{* * *} \\
{[0.002]}\end{array}$ & $\begin{array}{l}-0.221 \\
{[0.391]}\end{array}$ & $\begin{array}{l}-0.001 \\
{[0.003]}\end{array}$ & $\begin{array}{c}0.007 \\
{[0.022]}\end{array}$ & $\begin{array}{l}-0.012 \\
{[0.029]}\end{array}$ & $\begin{array}{c}0.000 \\
{[0.046]}\end{array}$ \\
\hline 3rd + child & $\begin{array}{c}-0.018^{* * *} \\
{[0.002]}\end{array}$ & $\begin{array}{l}-0.579 \\
{[0.439]}\end{array}$ & $\begin{array}{c}0.010^{* * *} \\
{[0.003]}\end{array}$ & $\begin{array}{c}-0.118^{* * *} \\
{[0.024]}\end{array}$ & $\begin{array}{c}-0.143^{* * *} \\
{[0.032]}\end{array}$ & $\begin{array}{l}-0.090^{*} \\
{[0.050]}\end{array}$ \\
\hline 2nd child $\times$ Mother's height & & $\begin{array}{c}0.151 \\
{[0.247]}\end{array}$ & & & & \\
\hline 3rd + child $\times$ Mother's height & & $\begin{array}{c}0.293 \\
{[0.277]}\end{array}$ & & & & \\
\hline 2nd child $\times$ Open defecation & & & & $\begin{array}{c}0.049 \\
{[0.034]}\end{array}$ & & \\
\hline 3 rd + child $\times$ Open defecation & & & & $\begin{array}{c}0.032 \\
{[0.037]}\end{array}$ & & \\
\hline 2nd child $\times \%$ non-resident among children & & & & & $\begin{array}{c}0.342 \\
{[0.209]}\end{array}$ & \\
\hline 3rd + child $\times \%$ non-resident among children & & & & & $\begin{array}{l}0.445^{*} \\
{[0.229]}\end{array}$ & \\
\hline 2nd child $\times$ Land scarcity & & & & & & $\begin{array}{c}0.008 \\
{[0.017]}\end{array}$ \\
\hline 3rd + child $\times$ Land scarcity & & & & & & $\begin{array}{l}-0.005 \\
{[0.019]}\end{array}$ \\
\hline $\begin{array}{l}\text { Africa mean of outcome } \\
\text { Household \& age controls } \\
\text { Observations }\end{array}$ & $\begin{array}{c}0.072 \\
\text { Yes } \\
199,665\end{array}$ & $\begin{array}{l}-1.435 \\
\text { Yes } \\
172,630\end{array}$ & $\begin{array}{c}0.157 \\
\text { Yes } \\
173,570\end{array}$ & $\begin{array}{l}-1.435 \\
\text { Yes } \\
168,840\end{array}$ & $\begin{array}{l}-1.435 \\
\text { Yes } \\
174,157\end{array}$ & $\begin{array}{l}-1.435 \\
\text { Yes } \\
174,157\end{array}$ \\
\hline
\end{tabular}

Notes: Standard errors are clustered by mother and appear in brackets. Asterisks denote significance: $* p<.10, * * p<.05, * * * p<.01$. Control variables included are survey month controls, child age dummies, mother's age at birth, household covariates, and household covariates, child's age, and mother's age at birth interacted with India. Column 2 additionally controls for household covariates, child's age, and mother's age at birth $\times$ Mother's height. Column 4 additionally controls for household covariates, child's age, and mother's age at birth $\times$ Open defecation. Open defecation is a dummy variable that equals 1 if the mother reports that the household has no toilet facility. Column 5 also controls for household covariates, child's age, and mother's age at birth $\times \%$ non-resident among children. Column 6 for household covariates, child's age, and mother's age at birth $\times$ Land scarcity. Land scarcity is defined as the log of the respondent's country's total population in 1961 divided by its land area in square km in 1961. The main effect India is included in all columns but not shown. In Column 1, the sample is restricted to children ages 13-59 months, as infant mortality is censored for children less than 1 year old. See Data Appendix for further details. 
Appendix Table 6: Adult food consumption and hemoglobin

\begin{tabular}{|c|c|c|c|c|}
\hline \multirow[t]{2}{*}{ Sample: } & \multicolumn{2}{|c|}{ African $\mathscr{E}$ Indian mothers } & \multicolumn{2}{|c|}{ Indian parents } \\
\hline & $\begin{array}{l}\text { Food con- } \\
\text { sumption } \\
\text { index } \\
(1)\end{array}$ & $\begin{array}{c}\text { Hemoglobin } \\
\text { level } \\
(2)\end{array}$ & $\begin{array}{l}\text { Food con- } \\
\text { sumption } \\
\text { index } \\
(3)\end{array}$ & $\begin{array}{c}\text { Hemoglobin } \\
\text { level } \\
(4)\end{array}$ \\
\hline India $\times$ Has 1 child & & $\begin{array}{c}-0.618^{* * *} \\
{[0.199]}\end{array}$ & & \\
\hline India $\times$ Has $2+$ children & $\begin{array}{r}-0.140^{*} \\
{[0.081]}\end{array}$ & $\begin{array}{c}-0.952^{* * *} \\
{[0.238]}\end{array}$ & & \\
\hline India $\times$ Has 1 child $\times$ Not pregnant & & $\begin{array}{l}0.263 \\
{[0.208]}\end{array}$ & & \\
\hline India $\times$ Has $2+$ children $\times$ Not pregnant & $\begin{array}{c}0.093 \\
{[0.085]}\end{array}$ & $\begin{array}{l}0.509^{* *} \\
{[0.248]}\end{array}$ & & \\
\hline Mother $\times$ Has 1 child & & & $\begin{array}{l}-0.047 \\
{[0.166]}\end{array}$ & $\begin{array}{l}-0.448 \\
{[0.348]}\end{array}$ \\
\hline Mother $\times$ Has $2+$ children & & & $\begin{array}{l}-0.236 \\
{[0.196]}\end{array}$ & $\begin{array}{r}-0.775^{*} \\
{[0.420]}\end{array}$ \\
\hline Mother $\times$ Has 1 child $\times$ Not pregnant & & & $\begin{array}{c}0.049 \\
{[0.175]}\end{array}$ & $\begin{array}{l}-0.165 \\
{[0.366]}\end{array}$ \\
\hline Mother $\times$ Has $2+$ children $\times$ Not pregnant & & & $\begin{array}{c}0.224 \\
{[0.205]}\end{array}$ & $\begin{array}{c}0.017 \\
{[0.439]}\end{array}$ \\
\hline $\begin{array}{l}\text { Africa mean of outcome } \\
\text { p-value: India } \times \text { Has } 2+\text { children } \times \text { Not preg } \\
\text { p-value: India } \times \text { Has } 1 \text { child } \times \text { Not preg } \\
\text { p-value: Mother } \times \text { Has } 1 \text { child } \times \text { Not preg } \\
\text { p-value: Mother } \times \text { Has } 2+\text { children } \times \text { Not preg } \\
\text { Household \& age controls } \\
\text { Observations }\end{array}$ & $\begin{array}{c}\text { Yes } \\
59,928\end{array}$ & $\begin{array}{c}11.988 \\
0.000 \\
0.000\end{array}$ & $\begin{array}{c}0.978 \\
0.841 \\
\text { Yes } \\
40,076\end{array}$ & $\begin{array}{c}0.000 \\
0.000 \\
\text { Yes } \\
34,240\end{array}$ \\
\hline
\end{tabular}

Notes: Standard errors are clustered by mother and appear in brackets. Asterisks denote significance: ${ }^{*} p<.10,{ }^{* *}$ $p<.05,{ }^{* * *} p<.01$. In Columns 1-2, control variables included are survey month controls, household covariates, mother's age at birth, household covariates and mother's age at birth interacted with India, Not pregnant, and India*Not pregnant. In Column 1, the sample includes mothers who have given birth to at least 1 child in the last 3 years; data to construct the mother's food consumption index in a comparable way to India is available in 10 African surveys. In Column 2, the sample includes mothers who have given birth in the last 5 years or have never given birth; data on mother's hemoglobin level is available in 21 African surveys. In Column 3-4, the control variables included are household covariates, mother's age at birth, household covariates and mother's age at birth interacted with India, Mother, and India $\times$ Mother. The sample includes Indian women who have given birth to at least 1 child in the past 5 years or have never given birth and their husbands, if both answered consumption questions. Men whose wives are pregnant are also coded as pregnant, and the omitted category is men whose wives have never given birth. See Data Appendix for further details. 


\section{Data Appendix}

\section{DHS surveys used}

The data sets included from Sub-Saharan Africa are Democratic Republic of the Congo 2007 (V), Republic of the Congo (Brazzaville) 2005 (V), Cameroon 2004 (IV), Chad 2004 (IV), Ethiopia 2005 (V), Ghana 2008 (V), Guinea 2005 (V), Kenya 2008-9 (V), Liberia 2007 (V), Lesotho 2004 (IV), Lesotho 2009 (VI), Madagascar 2003-4 (IV), Mali 2006 (V), Malawi 2004 (IV), Niger 2006 (V), Nigeria 2008 (V), Namibia 2006-7 (V), Rwanda 2005 (V), Sierra Leone 2008 (V), Senegal 2005 (IV), Sao Tome 2008 (V), Swaziland 2006-7 (V), Tanzania 2004-5 (IV), Tanzania 2010 (VI), Uganda 2006 (V), Zambia 2007 (V), and Zimbabwe 2005-6 (V). The DHS questionnaire version (IV, V, or VI) is given in parentheses. The data set for India is India 2005-6 (NFHS-3).

\section{Height-for-age z-score}

For comparing height across children of different gender and age, we create normalized variables using the World Heath Organization (WHO) method (WHO Multicentre Growth Reference Study Group, 2006b). The WHO provides the distribution of height separately for boys and girls, by age in months from a reference population of children from Brazil, Ghana, India, Norway, Oman and the United States. Because child height has a skewed distribution, the WHO recommends a restricted application of the LMS method using a Box-Cox normal distribution. The formula used is as follows:

$$
\text { z-score }=\frac{(\text { observed value } / M)^{L-1}}{L \times S}
$$

The WHO provides the values of $M, L$ and $S$ for each reference population by gender and age. $M$ is the reference median value for estimating the population mean, $L$ is the power used to transform the data to remove skewness, and $S$ is the coefficient of variation.

\section{Child's age}

For all children whose anthropometric data are recorded, the DHS also provides measurement date. Our child age variable is in months, and is constructed by calculating the number of days elapsed between child's birth and measurement date, and then converting this age into months. When we refer to a child as $n$ months old, we mean the child is in its $n^{t h}$ month of life such that a child who is one week old is in its 1st month of life, hence 1 month old.

\section{Birth order}

Birth order is defined as birth order among children ever born to one's mother. Multiple births, such as twins, are assigned the same birth order. For a child born subsequent to a multiple birth, birth order is incremented by the size of the multiple birth, e.g., the next child born after firstborn twins is birth order 3 .

\section{Prenatal variables}

Total prenatal visits is collected for the most recent birth in the past 5 years. Hence, our sample is restricted to youngest living child from each family for this variable. It is available in all 27 African DHS's and the NFHS. It is the mother's self-report of the total number of prenatal visits during the pregnancy. It is 0 if the mother never went for a prenatal visit, and the maximum number of visits is top-coded at 20 .

Mother took iron supplements is collected for the most recent birth in the past 5 years. It is available in all 27 African DHS's and the NFHS. It is the mother's self-report of whether she took iron supplements during the pregnancy of her youngest living child.

Mother's total tetanus shots is collected for the most recent birth in the past 5 years. The exception is the Democratic Republic of the Congo (2007), which collected it for all births in the past 5 years; we restrict the sample to the most recent birth for consistency. It is available in all 27 African DHS's and the NFHS. It is the mother's self-report of the number of tetanus toxoid injections given during the pregnancy to avoid convulsions after birth. The DHS recorded having more than 7 injections as 7. 
Delivery at health facility is collected for all births in the past 5 years. It is available in all 27 African DHS's and the NFHS. It is calculated based on the mother's self-report of where child was delivered. Delivery at a home is defined as a delivery at any home, including the respondent's home, her parents' home, traditional birth attendant's home or some other home. Any delivery that did not occur at a home is considered a delivery at health facility.

\section{Postnatal variables}

Postnatal check within 2 months is collected for the most recent birth in the past 5 years. It is available in 13 African DHS's (Ghana 2008, Kenya 2008-9, Liberia 2007, Lesotho 2009, Nigeria 2008, Namibia 2006-7, Sierra Leone 2008, Sao Tome 2008, Swaziland 2006-7, Tanzania 2010, Uganda 2006, Zambia 2007, and Zimbabwe 2005-6) as well as the NFHS. It is the mother's self-report of whether the child received a postnatal check within 2 months after it was born.

Child taking iron pills is collected for all births in the past 5 years. It is available in 10 African DHS's (Ghana 2008, Kenya 2008-9, Liberia 2007, Nigeria 2008, Namibia 2006-7, Sierra Leone 2008, Sao Tome 2008, Swaziland 2006-7, Tanzania 2010, and Uganda 2006) as well as the NFHS. It is the mother's self-report of whether the child is currently taking iron pills.

Child's total vaccinations is collected for all births in the past 5 years. It is available in all 27 African DHS's and the NFHS. It is the mother's self-report of the total number of vaccinations the child has received to date from among those that the DHS collects data on: BCG, 3 doses of DPT, 4 doses of polio, and measles. Thus the value of child's total vaccinations is 9 if the child received all vaccines. The sample is restricted to children who should have completed their course of vaccinations, specifically those age 13-59 months, as the recommended age for the vaccinations is up to age 12 months.

\section{Other child outcomes}

Pooled inputs. We include regressions that pool all four prenatal inputs and three postnatal inputs, transforming continuous variables into dummy variables for being above the sample median. The dummy variables are: 1) total prenatal visits $>4 ; 2$ ) mother took iron supplements; 3) mother's total tetanus shots $>1$; 4) child was delivered at a health facility; 5) child is taking iron pills; 6) total vaccinations $>7$; 7) child had postnatal check within 2 months of birth.

Child's Hb level is the child's hemoglobin level in $\mathrm{g} / \mathrm{dl}$ adjusted by altitude. It is defined for children 6 months or older and is not available for 6 surveys: Chad 2004, Kenya 2008-9, Liberia 2007, Namibia 2006-7, Nigeria 2008, and Zambia 2007.

Infant mortality is an indicator for whether the child is deceased is collected for all births in the past 5 years. It is available in all 27 African DHS's and the NFHS. It is the mother's self-report of whether the child is deceased. The sample is restricted to children age 13-59 months because whether they died in infancy is censored for children under age 1 year.

Diarrhea in last 2 weeks is collected for all births in the past 5 years. It is available in all 27 African DHS's and the NFHS. It is the mother's self-report of whether the child had diarrhea in the 2 weeks before the survey.

\section{Maternal outcomes}

Wants more children is created based on the question, "Would you like to have another child, or would you prefer not to have more children?" It is coded as 0.5 if the mother said she is undecided whether she wants to have more children and 0 if she wants no more children or has been sterilized. This variable is missing if the woman is infecund or indicated that she has never had sex.

Mother's food consumption index is constructed based on the DHS and NFHS variables on mother's food consumption. Mother's food consumption is available in 10 African DHS's (Ghana 2008, Liberia 2007, Nigeria 2008, Namibia 2006-7, Sierra Leone 2008, Sao Tome 2008, Swaziland 2006-7, Uganda 2006, Zambia 2007, and Zimbabwe 2005-6). These surveys asked detailed questions about food and liquid items consumed in the last 24 hours to mothers who have given birth in the last three years. Based on this, we create indicators for whether the mother consumed something from the following five food groups in the previous day: eggs/fish/meat, milk/dairy, fruits, pulses/beans, and leafy vegetables. For instance, for the eggs/fish/meat group, eggs, fish, meat are three separate questions, and we create an indicator for whether 
mothers consumed any of the three food items for those who answered all three questions. The consumption index is generated by adding the five indicators. The NFHS has related but different questions about mother's food consumption. The survey asked all women how frequently they consume a specified food item. Hence we code daily consumption as 1 , weekly consumption as $1 / 7$, and occasionally and never as 0 to make the variable comparable to the ones from the African surveys. We generate variables indicating consumption of the same 5 food groups, and sum them to generate the consumption index. When comparing Indian and African women, we restrict the sample to women who are living with a child younger than 36 months for consistency across surveys. The NFHS also asked the same set of consumption questions to fathers, so Indian father's consumption is coded the same way.

Mother's hemoglobin level is collected for all women in some DHS's and the NFHS, and is available for a smaller sample of women whose household is selected for hemoglobin testing in other DHS's. Overall, mother's hemoglobin level is available in 21 African DHS's and the NFHS. It is adjusted by altitude in all surveys except for Republic of the Congo (Brazzaville) 2005 (V), and measured in g/dl. We restrict the sample to women who have given birth in the last 5 years or never given birth.

\section{Variables used in heterogeneity analyses}

Child sex ratio is calculated as the number of boys aged 0-6 years old over the number of girls aged 0-6 years old in the respondent's state-by-region (either urban or rural) and comes from the 2001 Indian census. Higher values indicate greater gender imbalance favoring boys.

Mother's height is measured for mothers of children born in the 5 years preceding the survey. It is available in all 27 African DHS's and the NFHS. Mother's height is converted to meters and is coded as missing if the height is less than 1.25 meters.

Open defecation is available for all births in the past 5 years in the full sample of 27 African DHS's and the NFHS. It is the mother's self-report of whether the household has no toilet facility.

$\%$ non-resident among children is calculated as the percentage of children aged 10 years or lower who are living outside of the household, calculated at the level of primary sampling unit (PSU). Children's age and whether they are living in the household are available in the full sample of 27 African DHS's. Each mother's total number of living children 10 years old or younger are calculated, and summed at the PSU level. Then, the percentage of such children living outside of the household is calculated.

Land scarcity is the calculated as the log of each country's total population in 1961 over its land area in square $\mathrm{km}$ in 1961 and comes from the Food and Agriculture Organization of the United Nations (FAO).

\section{Other variables}

DHS wealth index is calculated by the DHS as a summary measure of the household's standard of living. It is based on a household's ownership of selected assets, such as televisions and bicycles; materials used for housing construction; sources of drinking water; and toilet facilities. Through principal component analysis, the DHS assigns a factor score to each of the assets, generating a standardized asset score specific to each survey. Within each full survey sample, the variable has a mean of 0 and standard deviation of 1. Because our sample comprises the subsample of households with children under age 5, the mean and standard deviation per survey are not identically 0 and 1.

Mother is literate is available for the full sample of 27 African DHS's and the NFHS. It is the mother's self-report of whether she can read in any language.

Preceding birth interval is the number of months between the mother's second or higher birth and the birth directly preceding it. It is calculated using the age of the mother's children and is top-coded at 120 months.

\section{Sample definitions}

The main sample includes children age 1-59 months who have anthropometric data. There is a high rate of missing data for children in their 60th month of life, and hence we limit the sample to children who are 59 months old or younger. In Appendix Table 2, column (3,) Below median fertility indicates that children are either from India or from African countries with below median fertility. Fertility level is calculated as the mean number of children per mother for each African survey. Then the median value among the African surveys is used to determine which surveys have below median fertility values. Excludes 
Indian PSUs with $>5 \%$ ultrasound use indicates that the Indian sample has been restricted to children living in PSUs with an average ultrasound usage of $<5 \%$ as reported by the mother. Children with the same father is the sample restricted to households in which all children presumably have the same father. Such households meet the following conditions: the mother's total number of unions is 1, the firstborn child's age in years is smaller than or equal to the number of years since the parents' marriage, and the mother is currently married. Countries with similar GDP to India include 23 DHS's administered between 2004-2010 from countries that have height data available and that had a log GDP per capita within a 50\% upper and lower bound of India's 2005-6 log GDP per capita. These countries are: Benin 2006, Bolivia 2008, Burkina Faso 2010, Cambodia 2005, Cambodia 2010, Cameroon 2004, Chad 2004, Egypt 2005, Ghana 2008, Haiti 2005, Honduras 2005, Kenya 2008, Lesotho 2004, Lesotho 2009, Mali 2006, Moldova 2005, Nigeria 2008, Sao Tome and Principe 2008, Senegal 2005, Senegal 2010, Tanzania 2010, Timor-Leste 2009, Zambia 2007, Zimbabwe 2005, Zimbabwe 2010.

Europe, Central 83 West Asia includes 16 DHS's spanning 1995-2012 for European, Central and West Asian countries with height data available: Albania 2008-2009, Azerbaijan 2006, Armenia 2005 \& 2010, Jordan 2012, 2007 \& 2002, Moldova 2005, Turkey 2003 \& 1998, Kazakhstan 1999 \& 1995, Kyrgyz Republic 2012 \& 1997, Tajikistan 2012, and Uzbekistan 1996. 